\title{
Dating of ultramafic rocks from the Western Alps ophiolites discloses Late Cretaceous subduction ages in the Zermatt-Saas Zone
}

\author{
GISELLA REBAY*†, DAVIDE ZANONI \\ PIETRO LUONI $\$$, MASSIMO TIEPOLO $\$$ \& MARIA IOLE SPALLA \\ *Università degli Studi di Pavia, Dipartimento di Scienze della Terra e dell’Ambiente, Via Ferrata, 1 - 27100 Pavia, Italy \\ tUniversità degli Studi di Milano, Dipartimento di Scienze della Terra 'A. Desio', Via Mangiagalli, \\ 34 - 20133 Milano, Italy \\ §IGG-CNR U.O.S. - Pavia, Via Ferrata, 1 - 27100 Pavia, Italy
}

(Received 28 October 2016; accepted 13 March 2017; first published online 3 May 2017)

\begin{abstract}
The Zermatt-Saas Zone was part of the Middle to Late Jurassic Tethyan lithosphere that underwent oceanic metamorphism during Mesozoic time and subduction during Eocene time (HP to UHP metamorphism). In upper Valtournanche, serpentinite, metarodingite and eclogite record a dominant S2 foliation that developed under $2.5 \pm 0.3 \mathrm{GPa}$ and $600 \pm 20^{\circ} \mathrm{C}$ during Alpine subduction. Serpentinites contain clinopyroxene and rare zircon porphyroclasts. Clinopyroxene porphyroclasts show fringes within S2 with similar compositions to that of grains defining S2. Zircon cores show zoning typical of magmatic growth and thin fringes parallel to the S2 foliation. These features indicate crystallization of clinopyroxene and zircon fringes during HP syn-D2 metamorphism, related to the Alpine subduction. The U-Pb zircon dates for cores and fringes reveal crystallization at $165 \pm 3.2 \mathrm{Ma}$ and $65.5 \pm 5.6 \mathrm{Ma}$, respectively. The Middle Jurassic dates are in agreement with the known ages for the oceanic accretion of the Tethyan lithosphere. The Late Cretaceaous - Paleocene dates suggest that the Zermatt-Saas Zone experienced high-pressure to ultra-high-pressure (HP-UHP) metamorphism at $c$. $16 \mathrm{Ma}$ earlier than previously reported. This result is in agreement with the evidence that in the Western Alps the continental Sesia-Lanzo Zone reached the subduction climax at least from $70 \mathrm{Ma}$ and was exhumed during ongoing oceanic subduction. Our results are further evidence that the Zermatt-Saas ophiolites diachronically recorded heterogeneous HP-UHP metamorphism.
\end{abstract}

Keywords: serpentinites, subduction metamorphism, microstructural analysis, U-Pb dating, Tethys opening

\section{Introduction}

Ophiolites represent oceanic remnants in mountain chains and their tracking, together with the reconstruction of their structural and metamorphic history, is still one of the basic tools for understanding the dynamics of collisional chain development. In the Alps, the key significance of ophiolites in geodynamics was long understood before the birth of plate tectonics (e.g. Brongniart, 1813; Argand, 1911; Steinmann, 1927). Since the first geological research within the Alps ophiolites from the Piedmont zone have been a favourable investigation object (Dal Piaz, 2010), especially in the exploration of deformation and mineral transformation histories of high-pressure (HP) and ultra-high-pressure (UHP) units of the Zermatt-Saas Zone (ZSZ). In the last years a debate developed on this portion of the Piedmont zone, regarding whether the pressure-temperature $(P-T)$ conditions registered by ZSZ rocks are largely uniform or if different portions of ZSZ recorded different $P-T$-peak conditions and underwent different exhumation paths over dif-

†Author for correspondence: gisella.rebay@unipv.it ferent time spans (e.g. Lapen et al. 2003; Li, Rahn \& Bucher, 2004; Angiboust et al. 2009; Groppo, Beltrando \& Compagnoni, 2009; Angiboust \& Agard, 2010; de Meyer et al. 2014; Skora et al. 2015; Weber \& Bucher, 2015; Weber et al. 2015). This last view has been recently reinforced by multiscalar structural and petrological analysis supported by detailed field mapping (Rebay, Spalla \& Zanoni, 2012; Weber \& Bucher, 2015; Zanoni, Rebay \& Spalla, 2016). The multiscalar analytical approach could be deeply reinforced by careful geochronological work, and becomes important in understanding the critical size of oceanic units able to record a homogeneous structural and metamorphic evolution during burial and exhumation paths in a subduction system. This means identifying volumes that have completed, remaining intact, their tectonic trajectory during a given time span. In addition, this allows light to be shed on how the coupling and decoupling of tectonic units can occur in the subduction mantle wedge or in the orogenic wedge during continental collision (e.g. Cloos, 1982; Chemenda et al. 1995; Stoeckhert \& Gerya, 2005; Baumann, Gerya \& Connolly, 2010; Roda, Marotta \& Spalla, 2010; Gerya, 2011; Malatesta et al. 2012, 2016; Roda, 


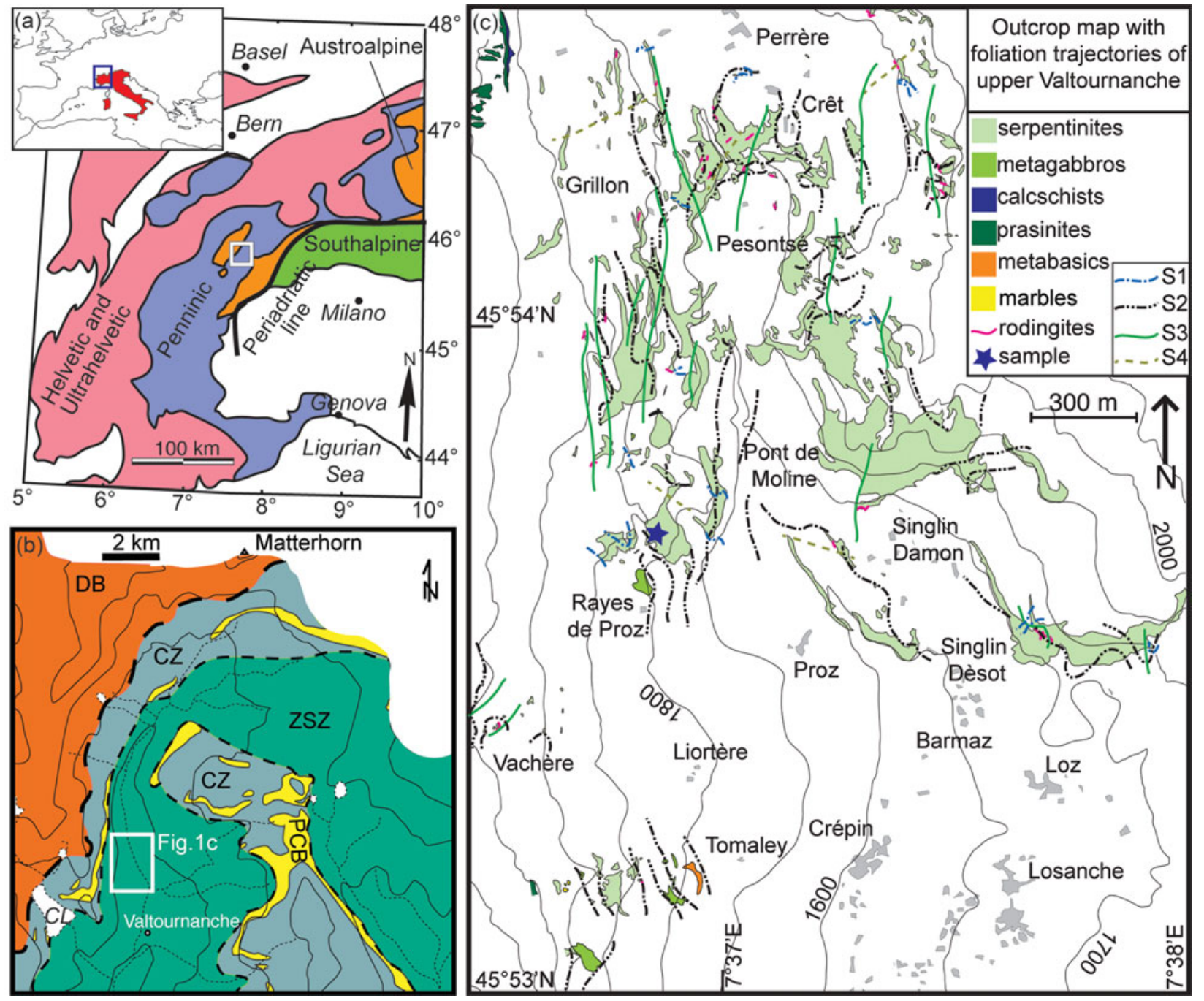

Figure 1. (Colour online) Geological and structural outline of the upper Valtournanche. (a) Tectonic sketch map of the Western Alps and its location within Europe and the Mediterranean region. (b) Interpretative tectonic sketch of the upper Valtournanche redrawn from the geotectonic map of the Aosta Valley (De Giusti et al. 2003); area indicated by the thick white square in (a). ZSZ - ZermattSaas Zone; PCB - Pancherot-Cime Bianche-Bettaforca unit; CZ - Combin Zone; DB - Dent Blanche nappe; CL - Cignana Lake. (c) Outcrop map with the foliation trajectories of the metaophiolites of the upper Valtournanche (ZSZ), synthesized from an original mapping (unpublished) at 1:5000 scale. Relative chronology of superimposed foliation is shown in the legend. Topography redrawn from the technical map of the Val d'Aosta Regional Administration without hydrography.

Spalla \& Marotta, 2012). Different subduction dynamics can result in the formation of tectonic units with different sizes and different ages, sharing a coherent structural and metamorphic evolution.

The main goal of this contribution is to present new age data on microstructural sites selected on the basis of a well-defined chronology of superimposed structures and metamorphic imprints at the regional scale, and to implement the chronological outline of eclogitized ZSZ ophiolites from the upper Valtournanche serpentinites in order to take some steps towards a better constrained regional framework.

\section{Geological setting}

The ZSZ, together with the Combin Zone (CZ), represents a Tethyan ocean relict that comprises rocks variously affected by oceanic- and subduction-related metamorphism, which now are transposed along the axial belt of the Western Alps (Caron et al. 1984; Reddy, Wheeler \& Cliff, 1999; Dal Piaz, 2010; Spalla et al. 2010). These two zones are tectonically sandwiched between the continental Monte Rosa (beneath) and Dent Blanche - Sesia Lanzo nappes (above) that belong to the Penninic and Austroalpine domains, respectively (e.g. Bearth, 1967; Polino, Dal Piaz \& Gosso, 1990). The ZSZ (Fig. 1a, b) underlies the CZ and, due to their different lithostratigraphic and metamorphic features, these two units have been interpreted as deriving from the oceanic lithosphere and from the ocean-continent transition zone, respectively (e.g. Dal Piaz \& Ernst, 1978; Dal Piaz et al. 1981). In the upper Valtournanche, ZSZ and CZ are separated by slices of pre-Alpine continental rocks and schists deriving 
Table 1. Summary of age data for Western Alps ophiolites and peak $P-T$ conditions for Zermatt-Saas Zone

\begin{tabular}{|c|c|c|c|c|c|c|c|}
\hline Key & Locality & Rock & Dating method; mineral & Age (Ma) & Peak $P-T$ conditions & Event & Reference \\
\hline \multicolumn{8}{|c|}{ Zermatt-Saas Zone } \\
\hline & Alallin glacier & Metagabbro & $\mathrm{U}-\mathrm{Th}-\mathrm{Pb}$; zircon & $164.0 \pm 2.7$ & & Emplacement & Rubatto, Gebauer \& Fanning, 1998 \\
\hline & Mellichen & Leucogabbro & $\mathrm{U}-\mathrm{Th}-\mathrm{Pb}$; zircon & $163.5+1.8$ & & Emplacement & Rubatto, Gebauer \& Fanning, 1998 \\
\hline & Tasch Valley & Metasediment & $\mathrm{U}-\mathrm{Th}-\mathrm{Pb}$; zircon & $153-173$ & & Deposition & Rubatto, Gebauer \& Fanning, 1998 \\
\hline & Cignana & Metasediment & $\mathrm{U}-\mathrm{Th}-\mathrm{Pb}$; zircon & $161 \pm 11$ & & Deposition & Rubatto, Gebauer \& Fanning, 1998 \\
\hline 3 & Triftji & Metapelite & $\begin{array}{l}\mathrm{Rb}-\mathrm{Sr} \text {; garnet phengite } \\
\text { inclusion }\end{array}$ & $\begin{array}{l}44.86 \pm 0.49 \text { to } \\
43.6 \pm 1.8\end{array}$ & & Prograde & de Meyer et al. 2014 \\
\hline 3 & Triftji & Metapelite & $\mathrm{Rb}-\mathrm{Sr}$; phengite (matrix) & $\begin{array}{l}40.01 \pm 0.51 \text { to } \\
39.5 \pm 1.1\end{array}$ & & Prograde & de Meyer et al. 2014 \\
\hline 5 & Pfulwe & Eclogite & Lu-Hf; garnet & $48.9 \pm 2.8$ & & Prograde & Skora et al. 2015 \\
\hline 12 & Chamois & Eclogite & Lu-Hf; garnet & $52.6 \pm 1.7$ & & Prograde & Skora et al. 2015 \\
\hline 8 & Trockener Steg & $\begin{array}{l}\text { Eclogite } \\
\text { (continental) }\end{array}$ & Lu-Hf; garnet-whole-rock & $\begin{array}{r}56.5 \pm 2.7 \text { to } \\
58.2 \pm 1.4\end{array}$ & & Prograde & Weber et al. 2015 \\
\hline 11 & Cignana & Eclogite & $\begin{array}{l}\text { Lu-Hf; garnet-omphacite- } \\
\text { whole-rock }\end{array}$ & $48.8 \pm 2.1$ & & Prograde & Lapen et al. 2003 \\
\hline 11 & Cignana & Eclogite & REE; garnet & $70-80$ & & Prograde & Skora et al. 2009 \\
\hline 9 & Breuil & $\begin{array}{l}\text { Metabasalts and } \\
\text { metagabbros }\end{array}$ & & & $0.8-1.2 \mathrm{GPa}, 420-520^{\circ} \mathrm{C}$ & $\mathrm{HP}$ & Ernst \& Dal Piaz, 1978 \\
\hline 2 & Allalinhorn & Metagabbro & & & $\begin{array}{l}1.5 \mathrm{GPa}, \\
570-700^{\circ} \mathrm{C}\end{array}$ & HP & Chinner \& Dixon, 1973 \\
\hline 2 & Allalinhorn & Metagabbro & & & $2.5 \mathrm{GPa}, 610^{\circ} \mathrm{C}$ & HP & Bucher \& Grapes, 2009 \\
\hline 2 & Allalinhorn & Metabasalts & & & $2.3-2.5 \mathrm{GPa}, 530-555^{\circ} \mathrm{C}$ & HP & Angiboust et al. 2009 \\
\hline 6 & Zermatt & Metabasites & & & $1.4 \mathrm{GPa}, 600^{\circ} \mathrm{C}$ & HP & Oberhänsli 1980 \\
\hline 6 & Zermatt & Metabasites & & & $1.75-2.0 \mathrm{GPa}, 550-600^{\circ} \mathrm{C}$ & HP & Barnicoat 1988 \\
\hline 8 & Trockener Steg & $\begin{array}{l}\text { Eclogite } \\
\text { (continental) }\end{array}$ & & & $2.2-2.3 \mathrm{GPa}, 515-645^{\circ} \mathrm{C}$ & HP & Weber \& Bucher, 2015 \\
\hline 8 & Trockener Steg & Eclogite & & & 2.2-2.3 GPa, $450-550^{\circ} \mathrm{C}$ & HP & Weber \& Bucher, 2015 \\
\hline 7 & Lichenbretter & Serpentinites & & & 2.0-2.5 GPa, $600-650^{\circ} \mathrm{C}$ & HP & Li, Rahn \& Bucher, 2004 \\
\hline 7 & $\begin{array}{l}\text { Riffelhorn- } \\
\text { Gornergrat }\end{array}$ & Serpentinites & & & $2.0-2.5 \mathrm{GPa}, 600-650^{\circ} \mathrm{C}$ & HP & Li, Rahn \& Bucher, 2004 \\
\hline 13 & St Jacques & Eclogite & Lu-Hf; garnet & $39.2 \pm 1.6$ & $0.8-1.2 \mathrm{GPa}, 420-520^{\circ} \mathrm{C}$ & HP & $\begin{array}{l}\text { Skora et al. 2015; Ernst \& Dal } \\
\quad \text { Piaz, } 1978\end{array}$ \\
\hline 5 & Pfulwe & Eclogite & Lu-Hf; garnet-whole- rock & $48.9 \pm 4.8$ & $1.75-2.0 \mathrm{GPa}, 550-600^{\circ} \mathrm{C}$ & HP & $\begin{array}{l}\text { Mahlen et al. 2006; Barnicoat \& } \\
\quad \text { Fry } 1986\end{array}$ \\
\hline 1 & Saas Fee & Eclogite & Lu-Hf; garnet & $\begin{array}{r}38.1 \pm 2.7 \text { to } \\
\quad 40.7 \pm 1.8\end{array}$ & & HP & Skora et al. 2015 \\
\hline 1 & Saas Fee & Metagabbro & & & $\begin{array}{l}2.5 \mathrm{GPa} \\
650^{\circ} \mathrm{C}\end{array}$ & HP & Meyer 1983 \\
\hline 1 & Saas Fee & Metabasites & & & $\begin{array}{l}2.5 \mathrm{GPa} \\
650^{\circ} \mathrm{C}\end{array}$ & HP & Bucher \& Frey 1994 \\
\hline 10 & Valtournenche & Serpentinites & & & $\begin{array}{l}2.2-2.8 \mathrm{GPa}, \\
600^{\circ} \mathrm{C}\end{array}$ & HP-UHP & Rebay, Spalla \& Zanoni, 2012 \\
\hline 10 & Valtournenche & Rodingites & & & $2.3-2.8 \mathrm{GPa}, 580-660^{\circ} \mathrm{C}$ & HP-UHP & Zanoni, Rebay \& Spalla, 2016 \\
\hline 5 & Pfulwe & Metabasalts & & & $2.5-3.0 \mathrm{GPa}, 550-600^{\circ} \mathrm{C}$ & UHP & Bucher et al. 2005 \\
\hline 3 & Mellichen & Leucogabbro & $\mathrm{U}-\mathrm{Th}-\mathrm{Pb}$; zircon & $48.8 \pm 2.9$ & & UHP & Rubatto, Gebauer \& Fanning, 1998 \\
\hline 3 & Mellichen & Leucogabbro & $\mathrm{U}-\mathrm{Th}-\mathrm{Pb}$; zircon & $40.3 \pm 9.2$ & & UHP & Rubatto, Gebauer \& Fanning, 1998 \\
\hline 3 & Mellichen & Metabasalts & & & $2.5-3.0 \mathrm{GPa}, 550-600^{\circ} \mathrm{C}$ & UHP & Bucher et al. 2005 \\
\hline 11 & Cignana & Eclogite & $\mathrm{Sm}-\mathrm{Nd}$; garnet & $40.6 \pm 2.6$ & $2.6-3.0 \mathrm{GPa}, c .600^{\circ} \mathrm{C}$ & UHP & $\begin{array}{c}\text { Amato et al. 1999; van der Klauw, } \\
\text { Reinecke \& Stöckhert, } 1997\end{array}$ \\
\hline
\end{tabular}


Table 1. Continued

\begin{tabular}{|c|c|c|c|c|c|c|c|}
\hline Key & Locality & Rock & Dating method; mineral & Age (Ma) & Peak $P-T$ conditions & Event & Reference \\
\hline 11 & Cignana & Eclogite & $\mathrm{Sm}-\mathrm{Nd}$; garnet & $52 \pm 18$ & & UHP & Bowtell, Cliff \& Barnicoat,1994 \\
\hline 11 & Cignana & Eclogite & U-Th-Pb; zircon & $44.1 \pm 0.7$ & & UHP & Rubatto, Gebauer \& Fanning, 1998 \\
\hline 11 & Cignana & Metasediment & $\mathrm{U}-\mathrm{Th}-\mathrm{Pb}$; zircon & $44.1 \pm 0.7$ & $\begin{array}{l}2.7-3.0 \mathrm{GPa}, \\
600^{\circ} \mathrm{C}\end{array}$ & UHP & $\begin{array}{l}\text { Rubatto, Gebauer \& Fanning, } \\
\text { 1998; Reinecke 1995, } 1998\end{array}$ \\
\hline 11 & Cignana & Metasediments & $\begin{array}{l}\text { Ar-Ar; garnet phengite } \\
\text { inclusion }\end{array}$ & $43.2 \pm 1.144 .4 \pm 1.5$ & & UHP & Gouzu et al. 2006; Reinecke, 1991 \\
\hline 11 & Cignana & Quarzite & $\mathrm{Rb}-\mathrm{Sr}$; phengite & $40.7 \pm 0.1$ & $2.6-2.8 \mathrm{GPa}, 590-630^{\circ} \mathrm{C}$ & UHP-retrograde & Skora et al. 2015; Reinecke, 1991 \\
\hline \multirow[t]{8}{*}{1} & Saas Fee & Calcshists & $\mathrm{Rb}-\mathrm{Sr}$; phengite & $39.5 \pm 0.1$ & & HP-retrograde & Skora et al. 2015 \\
\hline & Cignana & Quarzite & $\begin{array}{l}\mathrm{Rb}-\mathrm{Sr} \\
\quad \text { whole-rock-phengite }\end{array}$ & $38 \pm 2$ & & Retrograde & Amato et al. 1999 \\
\hline & Tasch Valley & Metapelite & $\begin{array}{l}\mathrm{Rb}-\mathrm{Sr} ; \\
\text { whole-rock-phengite }\end{array}$ & $38 \pm 2$ & & Retrograde & Amato et al. 1999 \\
\hline & Cignana & Metasediments & $\mathrm{Ar}-\mathrm{Ar}$; phengite (matrix) & 42-37 (plateaux age) & & Retrograde & Gouzu et al. 2006 \\
\hline & Cignana (UU) & Metabasite & $\mathrm{K}-\mathrm{Ar}$; phengite & $38-41$ & & Retrograde & Gouzu et al. 2016 \\
\hline & Cignana (UU) & Metasediments & $\mathrm{K}-\mathrm{Ar}$; phengite & $38-41$ & & Retrograde & Gouzu et al. 2016 \\
\hline & Cignana (LU) & Eclogite & $\mathrm{K}-\mathrm{Ar}$; paragonite & $37-38$ & & Retrograde & Gouzu et al. 2016 \\
\hline & Cignana (LU) & Eclogite & $\mathrm{K}-\mathrm{Ar}$; phengite & $37-38$ & & Retrograde & Gouzu et al. 2016 \\
\hline \multicolumn{8}{|c|}{ Combin Zone } \\
\hline & Cignana (LCU) & Pelitic shist & $\mathrm{K}-\mathrm{Ar}$; phengite & $39-41$ & & Retrograde & Gouzu et al. 2016 \\
\hline & Cignana (LCU) & Piemontite shist & $\mathrm{K}-\mathrm{Ar}$; phengite & $39-41$ & & Retrograde & Gouzu et al. 2016 \\
\hline & Cignana (LCU) & Eclogite & $\mathrm{K}-\mathrm{Ar}$; paragonite & $39-41$ & & Retrograde & Gouzu et al. 2016 \\
\hline & Cignana (LCU) & $\begin{array}{l}\text { Mn-rich } \\
\text { metasediment }\end{array}$ & $\mathrm{K}-\mathrm{Ar}$; phengite & $39-41$ & & Retrograde & Gouzu et al. 2016 \\
\hline & Cignana & Calcshists & $\mathrm{K}-\mathrm{Ar}$; phengite & $36-40$ & & Retrograde & Gouzu et al. 2016 \\
\hline \multicolumn{4}{|c|}{ Antrona } & & & Emplacement & Liati, Froitzheim \& Fanning. 2005 \\
\hline & $\begin{array}{l}\text { Passo del } \\
\text { Mottone }\end{array}$ & Metabasics & $\mathrm{Pb}-\mathrm{U}$; zircon & $158 \pm 17$ & & Emplacement & Liati, Froitzheim \& Fanning, 2005 \\
\hline & Quarata & Metabasics & $\mathrm{Pb}-\mathrm{U}$; zircon & $155.6 \pm 2.1$ & & Emplacement & Liati, Froitzheim \& Fanning, 2005 \\
\hline & Hinterrhein area & Metagabbro & $\mathrm{Pb}-\mathrm{U}$; zircon & $161 \pm 3.9$ & & Emplacement & Liati, Froitzheim \& Fanning, 2005 \\
\hline & $\begin{array}{l}\text { Passo del } \\
\text { Mottone }\end{array}$ & Amphibolite & $\mathrm{Pb}-\mathrm{U}$; zircon & $38.5 \pm 0.7$ & & $\mathrm{HP}$ & Liati, Froitzheim \& Fanning, 2005 \\
\hline & Alpe la Balma & Eclogite & Lu-Hf; garnet-whole-rock & $42-45.5$ & & $\mathrm{HP}$ & Herwartz et al. 2008 \\
\hline \multicolumn{8}{|c|}{ Monviso } \\
\hline & $\begin{array}{l}\text { Vernè (Val } \\
\text { Varaita) }\end{array}$ & Meta-plagiogranite & $\mathrm{U}-\mathrm{Pb}$; zircon & $152 \pm 2$ & & Emplacement & $\begin{array}{l}\text { Lombardo, Rubatto \& Castelli, } \\
2002\end{array}$ \\
\hline & Lago Superiore & Eclogite & $\mathrm{U}-\mathrm{Pb}$; zircon & $163 \pm 2$ & & Emplacement & Rubatto \& Hermann, 2003 \\
\hline & Lago Superiore & Eclogite & Lu-Hf; garnet-whole-rock & $49.2 \pm 1.2$ & & Prograde-HP & Duchêne et al. 1997 \\
\hline & Lago Superiore & Metamorphic vein & $\mathrm{U}-\mathrm{Pb}$; zircon & $45 \pm 1$ & & $\mathrm{HP}$ & Rubatto \& Hermann, 2003 \\
\hline & Lago Superiore & Eclogitic mylonite & $\mathrm{Rb}-\mathrm{Sr}$; phengite & $41.6 \pm 0.4$ & & HP & Cliff, Barnicoat \& Inger, 1998 \\
\hline & Lago Superiore & Eclogitic mylonite & $\begin{array}{l}\mathrm{Sm}-\mathrm{Nd} \text {; garnet and } \\
\text { clinoyroxene }\end{array}$ & $60 \pm 12$ & & HP & Cliff, Barnicoat \& Inger, 1998 \\
\hline & Lago Superiore & $\begin{array}{l}\text { Eclogitic } \\
\text { metagabbros }\end{array}$ & Ar-Ar; phengite & $48-53 \mathrm{Ma}$ & & $\mathrm{HP}$ & Monié \& Philippot, 1989 \\
\hline \multicolumn{8}{|c|}{ Voltri Group } \\
\hline & & Eclogite & Ar-Ar; phengite & $49.0 \pm 0.4$ & & HP & Federico et al. 2005 \\
\hline & & Blueschists & Ar-Ar; phengite & $43.5 \pm 1.7$ & & HP-retrograde & Federico et al. 2005 \\
\hline & & Metasediments & $\mathrm{Ar}-\mathrm{Ar}$; muscovite & $32.9 \pm 0.8$ & & Retrograde & Federico et al. 2005 \\
\hline
\end{tabular}



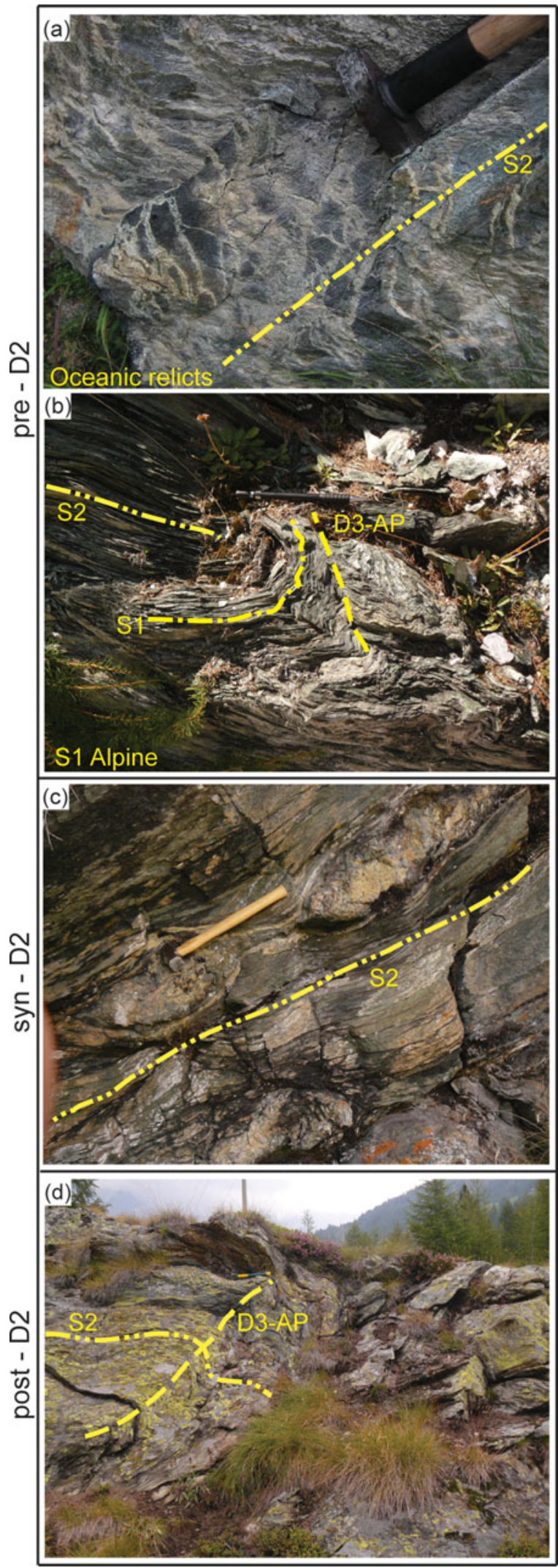

Figure 2. (Colour online) (a) Net of whitish amphiboleclinopyroxene-bearing veins intersected by $\mathrm{S} 2$ foliation. Hammer for scale. (b) S1 foliation folded during the development of D2 and post-D2 deformation stages. D2 is accompanied by the development of the $\mathrm{S} 2$ foliation and $\mathrm{D} 3$ produced only a folding (D3-AP = D3 axial plane). Pencil for scale. (c) Pervasive S2 foliation that wraps around rodingite boudins. Hammer for scale. (d) Metre-sized D3 fold. Hammer for scale. from Permian-Cretaceous sediments (Dal Piaz, 1999, 2010). The main difference between $Z$ SZ and CZ is the dominant metamorphic imprint: eclogite facies in the first and greenschist facies in the second. Despite the pervasive greenschist re-equilibration, $\mathrm{CZ}$ rocks preserve blueschist facies relicts, whereas remnants of eclogite facies assemblages have never been detected, even in the less-deformed rocks (Cartwright \& Barnicoat, 2002; Dal Piaz, 1974; Dal Piaz \& Ernst, 1978; Ring, 1995). The greenschist facies assemblages are extremely localized in the mostly eclogitized rocks of ZSZ and are mainly interpreted as exhumation-related metamorphic imprints (e.g. Cartwright \& Barnicoat, 2002; Ernst \& Dal Piaz, 1978); scattered relics predating the eclogite facies peak preserve blueschist facies mineral assemblages (e.g. Chinner \& Dixon, 1973; Ernst \& Dal Piaz, 1978). Metabasic rocks are the most explored to determine the Alpine metamorphic evolution of this portion of the Tethys ocean and results give a wide span of $P-T$ values in different portions of ZSZ: $2.5-3.0 \mathrm{GPa}$ and $550-600^{\circ} \mathrm{C}$ (Bucher et al. 2005); 1.9-2.2 GPa and 530-600 ${ }^{\circ} \mathrm{C}$ (Dale et al. 2009); and, south of the Aosta-Ranzola fault (St Marcel valley), $2.1 \pm 0.3 \mathrm{GPa}$ and $550 \pm 60^{\circ} \mathrm{C}$ (Martin et al. 2008). The metagabbros of the Swiss portion of the ZSZ record peak conditions of 2.5-2.8 GPa and 600$610{ }^{\circ} \mathrm{C}$ (Bucher \& Grapes, 2009) or alternatively 1.9 $2.2 \mathrm{GPa}$ and $500-580^{\circ} \mathrm{C}$ (Dale et al. 2009). Pressures from 2.7 to $>3.2 \mathrm{GPa}$ and temperatures of $590-630^{\circ} \mathrm{C}$ are estimated at Lago di Cignana (e.g. Reinecke, 1991, 1998; van der Klauw, Reinecke \& Stöckhert, 1997; Groppo, Beltrando \& Compagnoni, 2009), where microdiamonds have also been found in oceanic metasedimentary rocks (Frezzotti et al. 2011). Peak $P-T$ estimates from serpentinites of the Swiss side are at 2.0 $2.5 \mathrm{GPa}$ and $600-650^{\circ} \mathrm{C}$ (Li, Rahn \& Bucher, 2004), whereas in the Italian side they are at $2.2-2.8 \mathrm{GPa}$ and $580-620^{\circ} \mathrm{C}$ (Rebay, Spalla \& Zanoni, 2012). The latter estimates have recently been supported by $P-T$ peak conditions determined by thermodynamic modelling of the hosted eclogitized rodingites $(2.3-2.8 \mathrm{GPa}$ and $580-660^{\circ} \mathrm{C}$; Zanoni, Rebay \& Spalla, 2016). All these $P-T$ estimates led to the inference of trajectories indicating the occurrence of heterogeneous metamorphic evolutions in different portions of ZSZ. In contrast, different authors have suggested a homogeneous evolution for the entire ZSZ based on the assemblages from metabasites and calcschists, with peak conditions at $2.3 \pm 0.1 \mathrm{GPa}$ and $540 \pm 40^{\circ} \mathrm{C}$ (Angiboust et al. 2009; Angiboust \& Agard, 2010). In addition, part of the Monviso ophiolite has been interpreted as forming a single unit with the ZSZ, which would consist of a continuous slab, recording a coherent metamorphic evolution during the Alpine subduction (Angiboust et al. 2012). This interpretation differs from that of previous authors, suggesting that the Monviso is a complex of eclogitized ophiolitic slices accreted during the final stages of their exhumation on the basis of contrasted $P-T$ trajectories (Schwartz et al. 2000; Guillot et al. 2004). Consistent with a 


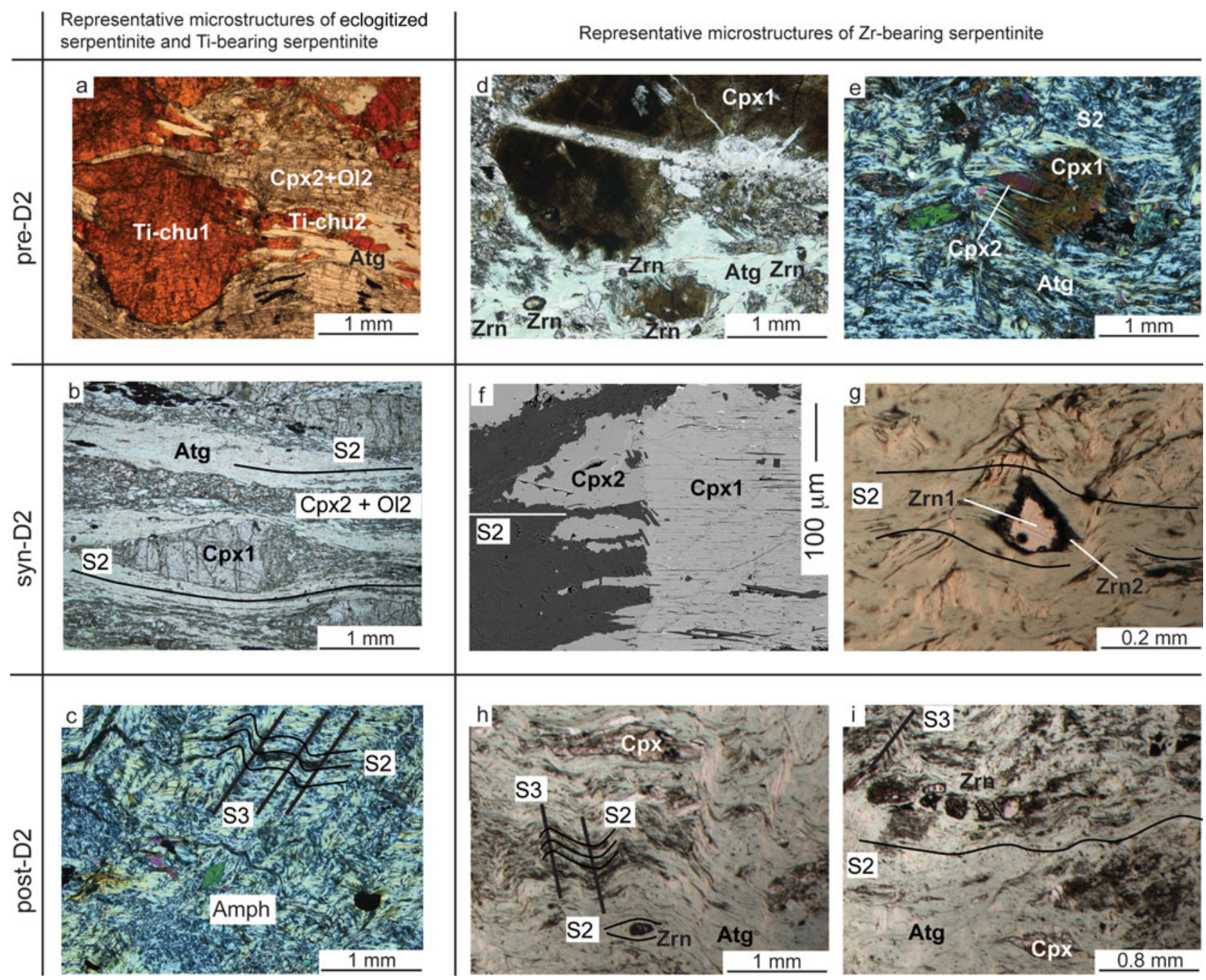

Figure 3. (Colour online) Microphotographs of $(\mathrm{a}-\mathrm{c})$ eclogitized and Ti-clinohumite-bearing serpentinite, and (d-i) of the zircon bearing eclogitized serpentinite sample. (a) Ti-clinohumite1 porphyroclasts (Ti-chu1) wrapped by S2 defined by Ti-clinohumite2 (Tichu2), olivine2 (O12), clinopyroxene2 (Cpx2) and antigorite (Atg); (b) syn-D2 mylonite with a clinopyroxene1 porphyroclast (Cpx1) and banded S2 foliation defined by clinopyroxene2 (Cpx2), olivine2 (O12) and antigorite (Atg); (c) S2 defined by antigorite overprinted by an incipient S3 crenulation cleavage; amphibole (Amph) porphyroblasts (note basal sections) show SPO parallel to S3; (d) large field view of the zircon-bearing serpentinite with a large, fractured, clinopyroxene (Cpx1) porphyroclast (dark) wrapped by $\mathrm{S} 2$, which is defined by antigorite (Atg), olivine2 and clinopyroxene2 (in the lower part there are five zircon porphyroclasts, Zrn); (e) clinopyroxene1 porphyroclast (Cpx1) with clinopyroxene2 (Cpx2) spikes parallel to S2, here defined by antigorite (Atg); (f) SEM backscattered image of a large clinopyroxene1 (Cpx1) with spikes of clinopyroxene2 (Cpx2) parallel to S2; (g) zircon (Zrn1) wrapped by antigorite defining S2, showing zircon2 (Zrn2) growths parallel to S2 (see zircon shape in CL image in Fig. 4c, h) clinopyroxene (Cpx) and zircon (Zrn) porphyroclasts wrapped by S2 overprinted by S3 crenulation cleavage; and (i) large zircon boudinaged within S2 that wraps a small clinopyroxene1 (Cpx1) porphyroclast, overprinted by S3 crenulation cleavage.

heterogeneous metamorphic evolution, Alpine ages indicate a wide time interval of re-equilibration during subduction of the ZSZ rocks and associated continental slivers (Table 1) of 80-38 Ma, with ages interpreted as referred to peak conditions as $52-38 \mathrm{Ma}$ (Bowtell, Cliff \& Barnicoat, 1994; Rubatto, Gebauer \& Fanning, 1998; Dal Piaz et al. 2001; Skora et al. 2009, 2015; Springer et al. 2009; de Meyer et al. 2014; Weber et al. 2015). Moreover, considering only $\mathrm{U}-\mathrm{Pb}$ zircon methods, such ages cluster at $c$. 48$40 \mathrm{Ma}$ (Table 1). Protolith ages indicate gabbro emplacement at 167-161 Ma and sediment deposition during 170-150 Ma (Table 1; Rubatto, Gebauer \& Fanning, 1998).

\section{Mesostructure}

Along the upper Valtournanche valley, between Valtournanche village and Perrère hydroelectric plant, serpentinite is the dominant lithotype. Hectometresized metagabbro bodies and up to a few metres thick rodingite boudins and dykes are associated with serpentinites, together with marbles and calcschists (Fig. 1c). The dominant fabric in serpentinites, metagabbros and rodingites is the tectonitic to mylonitic S2 foliation, and less-deformed domains contain textural and structural pre-D2 relicts (Fig. 2a-c). S2 is in turn overprinted by two groups of superimposed ductile structures (D3 and D4); all ductile 
Table 2. Trace element composition (ppm) of clinopyroxene and zircon (zircon grain names refer to Fig. 5)

\begin{tabular}{|c|c|c|c|c|c|c|c|c|c|c|c|c|c|c|c|}
\hline \multirow{2}{*}{$\begin{array}{l}\text { Mineral } \\
\text { Grain } \\
\text { Position }\end{array}$} & \multicolumn{6}{|c|}{ Cpx } & \multicolumn{9}{|c|}{ Zrn } \\
\hline & $\begin{array}{l}1 \\
\text { Core }\end{array}$ & $\begin{array}{l}1 \\
\text { Core }\end{array}$ & $\begin{array}{l}1 \\
\operatorname{Rim}\end{array}$ & $\begin{array}{l}2 \\
\text { Core }\end{array}$ & $\begin{array}{l}2 \\
\text { Core }\end{array}$ & $\begin{array}{l}3 \\
\text { Core }\end{array}$ & $\begin{array}{l}\text { 18_1a } \\
\text { Core dark }\end{array}$ & $\begin{array}{l}\text { 18_1b } \\
\text { Core light }\end{array}$ & $\begin{array}{l}\text { 18_03 } \\
\text { Fringe }\end{array}$ & $\begin{array}{l}\text { 18_03 } \\
\text { Core }\end{array}$ & $\begin{array}{l}\text { 18_05 } \\
\text { Core }\end{array}$ & $\begin{array}{l}\text { 18_06a } \\
\text { Core dark }\end{array}$ & $\begin{array}{l}\text { 18_06b } \\
\text { Core light }\end{array}$ & $\begin{array}{l}\text { 18_11a } \\
\text { Core light }\end{array}$ & $\begin{array}{l}\text { 18_11b } \\
\text { Core dark }\end{array}$ \\
\hline $\mathrm{Li}$ & 18.4 & 15.7 & 15.4 & 13.6 & 14.5 & 16.6 & $<1.84$ & 2.32 & $<1.26$ & $<0.00$ & 3.35 & $<0.00$ & $<2.07$ & $<1.66$ & $<0.00$ \\
\hline $\mathrm{Be}$ & 1.15 & 1.48 & 4.65 & 2.43 & $<2.26$ & 2.83 & 27.1 & $<0.00$ & $<14.04$ & $<11.40$ & $<12.41$ & $<0.00$ & $<0.00$ & $<12.42$ & $<8.76$ \\
\hline B & 4.94 & 3.72 & 8.98 & 6.97 & 3.97 & 4.27 & $<8.03$ & $<9.23$ & 16.48 & 14.18 & 66.13 & 14.84 & 11.73 & 23.48 & 35.83 \\
\hline $\mathrm{Na}$ & 6039 & 6187 & 5547 & 6370 & 5359 & 7102 & 10.8 & 136.0 & 22.3 & 103.6 & 9.9 & 15.6 & 30.3 & $<2.51$ & 120.8 \\
\hline $\mathrm{Sc}$ & 138 & 139 & 130 & 166 & 155 & 154 & 492 & 485 & 390 & 448 & 490 & 423 & 432 & 444 & 406 \\
\hline $\mathrm{Ti}$ & 2390 & 2602 & 1846 & 2707 & 2450 & 2296 & 37.9 & 60.2 & 14.7 & $<8.35$ & $<10.67$ & 12.6 & 46.6 & 20.1 & 36.1 \\
\hline V & 102 & 103 & 107 & 74.2 & 74.7 & 70.7 & 2.72 & $<1.50$ & 6.15 & 5.26 & $<1.88$ & $<1.39$ & 1.59 & $<1.29$ & $<1.37$ \\
\hline $\mathrm{Cr}$ & 1470 & 1830 & 538 & 84.0 & 79.4 & 85.0 & 24.7 & $<15.74$ & 108.0 & $<13.78$ & $<18.42$ & $<12.24$ & 13.8 & $<12.46$ & $<13.83$ \\
\hline Co & 35.7 & 34.9 & 31.3 & 41.3 & 36.1 & 37.4 & 0.67 & $<0.40$ & 7.69 & 0.4 & 2.04 & $<0.21$ & 1.96 & $<0.27$ & 0.7 \\
\hline $\mathrm{Ni}$ & 343 & 356 & 325 & 234 & 236 & 254 & $<1.69$ & $<1.59$ & 131 & 2.94 & 7.44 & 4.06 & 29.7 & $<1.16$ & 2.63 \\
\hline $\mathrm{Zn}$ & 114 & 119 & 109 & 190 & 144 & 135 & $<6.64$ & 32.6 & $<6.61$ & 5.28 & $<6.59$ & $<4.99$ & $<3.18$ & $<5.07$ & $<4.57$ \\
\hline $\mathrm{Rb}$ & 0.077 & $<0.030$ & 0.109 & 0.126 & $<0.035$ & 0.059 & 0.36 & 0.47 & $<0.25$ & 0.44 & $<0.23$ & 0.23 & 0.7 & 0.91 & 0.76 \\
\hline $\mathrm{Sr}$ & 12.4 & 12.4 & 12.5 & 13.1 & 15.0 & 13.4 & 0.75 & 1.07 & 0.42 & 0.73 & 0.84 & 0.44 & 0.55 & 0.58 & 0.88 \\
\hline Y & 402 & 410 & 483 & 465 & 407 & 449 & 1919 & 1828 & 1474 & 2381 & 2155 & 2693 & 1687 & 2651 & 3245 \\
\hline $\mathrm{Zr}$ & 118 & 117 & 93 & 137 & 118 & 124 & - & - & - & - & - & - & - & - & - \\
\hline $\mathrm{Nb}$ & 0.273 & 0.624 & 0.333 & 0.392 & 0.404 & 0.762 & 49.8 & 46.4 & 36.7 & 37.5 & 37.0 & 31.0 & 33.7 & 33.9 & 28.2 \\
\hline $\mathrm{Ba}$ & 0.039 & $<0.00$ & 0.61 & $<0.064$ & 0.108 & 0.409 & $<0.00$ & $<0.243$ & 0.36 & $<0.00$ & $<0.00$ & 0.2 & 0.22 & 0.2 & $<0.37$ \\
\hline $\mathrm{La}$ & 10.6 & 11.2 & 14.5 & 11.0 & 9.1 & 10.2 & 0.191 & 0.14 & 0.78 & 0.116 & 0.7 & 0.065 & 0.347 & 0.028 & 0.088 \\
\hline $\mathrm{Ce}$ & 50.9 & 55.8 & 76.4 & 57.3 & 48.2 & 56.0 & 14.7 & 13.4 & 10.6 & 8.6 & 14.9 & 9.8 & 14.2 & 9.2 & 10.1 \\
\hline $\operatorname{Pr}$ & 12.2 & 13.2 & 18.4 & 14.2 & 12.3 & 14.0 & 0.07 & 0.396 & 0.354 & 0.083 & 0.34 & 0.155 & 0.516 & 0.1 & 0.127 \\
\hline $\mathrm{Nd}$ & 86.6 & 90.4 & 116 & 102 & 89.3 & 97.1 & 3.63 & 3.13 & 1.21 & 1.76 & 3.37 & 3.55 & 5.97 & 1.79 & 3.64 \\
\hline $\mathrm{Sm}$ & 44.7 & 45.9 & 54.6 & 49.5 & 43.1 & 46.6 & 4.04 & 8.59 & 3.03 & 5.55 & 5.46 & 5.52 & 4.93 & 9 & 9.58 \\
\hline $\mathrm{Eu}$ & 7.74 & 8.19 & 9.05 & 9.5 & 8.56 & 9.33 & 1.16 & 1.69 & 1.09 & 2.33 & 2.88 & 2.56 & 2.27 & 2.33 & 3.41 \\
\hline $\mathrm{Gd}$ & 64.5 & 65.5 & 75.4 & 71.7 & 64.4 & 70.5 & 30.9 & 32.1 & 25.5 & 44.2 & 33.0 & 48.2 & 31.5 & 48.8 & 75.5 \\
\hline $\mathrm{Tb}$ & 11.5 & 12.3 & 14.4 & 13.7 & 11.8 & 12.5 & 12.64 & 14.2 & 8.07 & 15.8 & 12.05 & 17.2 & 11.3 & 18.1 & 24.3 \\
\hline Dy & 82.5 & 85.0 & 100.1 & 95.5 & 84.4 & 92.7 & 163 & 161 & 115 & 231 & 167 & 245 & 147 & 243 & 319 \\
\hline Но & 17.6 & 17.5 & 20.9 & 20.5 & 18.3 & 19.4 & 66.1 & 70.7 & 48.0 & 84.7 & 74.9 & 91.4 & 56.6 & 92.7 & 113 \\
\hline $\mathrm{Er}$ & 47.0 & 50.8 & 58.9 & 58.2 & 51.5 & 53.5 & 321 & 309 & 256 & 386 & 386 & 459 & 273 & 432 & 527 \\
\hline $\mathrm{Tm}$ & 6.66 & 6.77 & 8.41 & 8.01 & 7.5 & 7.79 & 66.0 & 64.5 & 57.4 & 76.6 & 79.9 & 91.8 & 59.1 & 90.1 & 108 \\
\hline $\mathrm{Yb}$ & 43.1 & 43.5 & 51.2 & 51.8 & 46.0 & 52.0 & 621 & 575 & 588 & 670 & 806 & 808 & 562 & 796 & 921 \\
\hline $\mathrm{Lu}$ & 6.16 & 6.35 & 7.28 & 8.04 & 6.94 & 6.99 & 127 & 114 & 121 & 130 & 145 & 161 & 114 & 154 & 166 \\
\hline $\mathrm{Hf}$ & 5.46 & 5.36 & 5.39 & 6.24 & 5.15 & 6.78 & 12546 & 12504 & 11558 & 11337 & 12349 & 10941 & 10415 & 11184 & 11229 \\
\hline $\mathrm{Ta}$ & 0.0145 & 0.0299 & 0.0233 & 0.0075 & 0.054 & 0.034 & 0.510 & 0.319 & 2.03 & 0.162 & 0.63 & 0.456 & 1.1 & 0.455 & 0.767 \\
\hline $\mathrm{Pb}$ & 0.286 & 0.219 & 0.331 & 0.283 & 0.286 & 0.329 & 0.210 & 0.470 & 0.430 & 0.400 & 0.780 & 0.231 & 0.232 & 0.263 & 0.310 \\
\hline Th & 0.0462 & 0.053 & 0.0365 & 0.082 & 0.102 & 0.0324 & 6.45 & 4.15 & 4.16 & 4.46 & 12.57 & 7.77 & 15.43 & 7.29 & 9.22 \\
\hline U & 0.0044 & $<0.0063$ & 0.0116 & 0.017 & 0.0077 & 0.0468 & 10.4 & 8.9 & 12.7 & 9.1 & 16.5 & 14.0 & 17.6 & 14.5 & 15.8 \\
\hline $\mathrm{Th} / \mathrm{U}$ & & & & & & & 0.62 & 0.46 & 0.33 & 0.49 & 0.76 & 0.55 & 0.88 & 0.50 & 0.58 \\
\hline
\end{tabular}



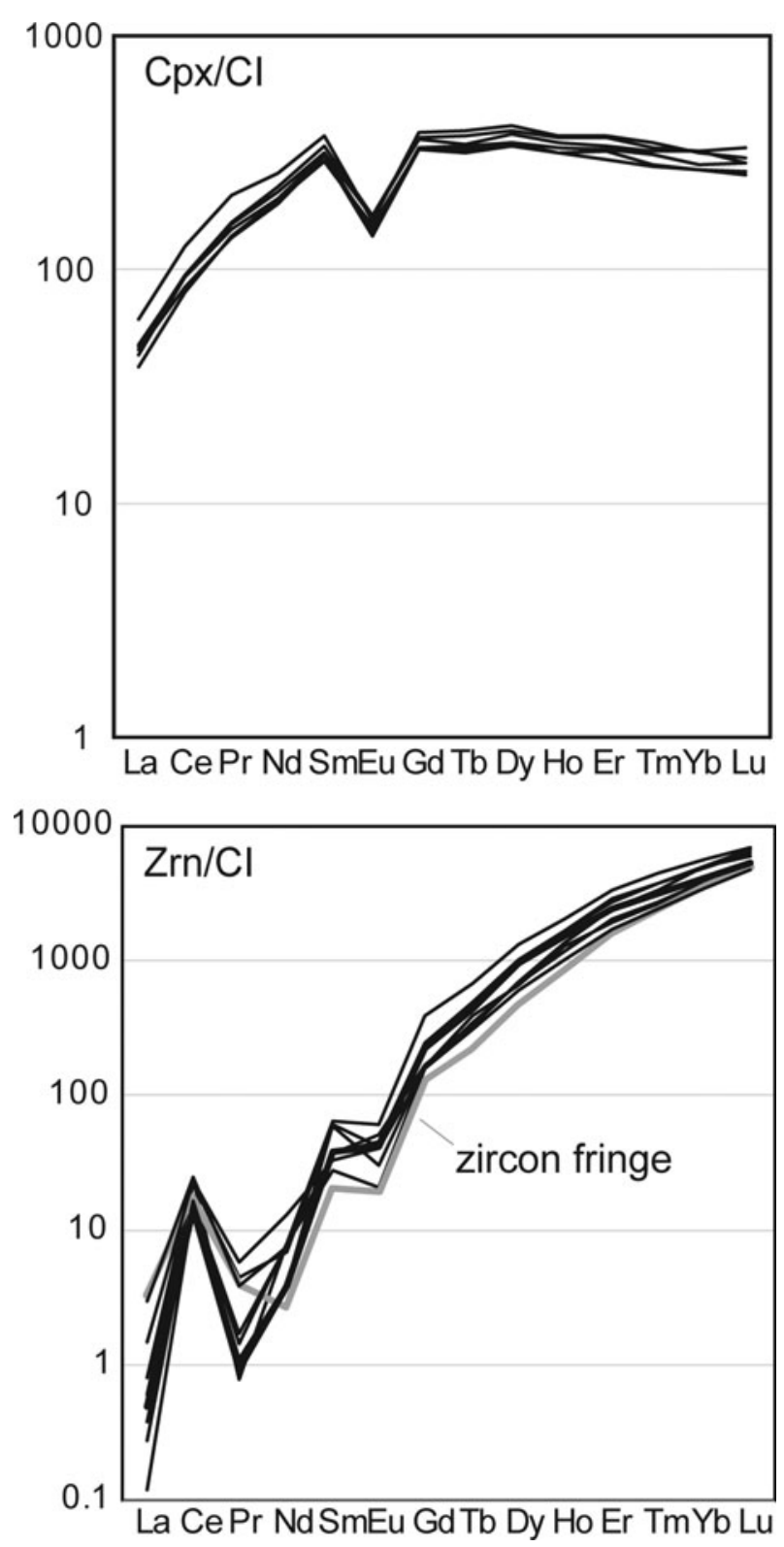

Figure 4. REE patterns (chondrite normalized) of clinopyroxene and zircon cores.

structures were mapped with spatial continuity (Fig. 1c) by means of multiscale structural analysis (Rebay, Spalla \& Zanoni, 2012; Zanoni et al. 2012; Zanoni, Rebay \& Spalla, 2016). S2 locally is mylonitic and associated with a tight to isoclinal folding that is characterized by a shallow west-dipping axial plane and a NNW-SSE shallow plunging axis. Contacts between serpentinites and metagabbros or rodingites are mainly reworked during the S2 development (see Zanoni, Rebay \& Spalla, 2016). In serpentinite, S2 is marked by Alpine HP-UHP mineral assemblages and is pre-dated by clinopyroxene porphyroclasts and amphibole-clinopyroxene-bearing vein nets (Fig. 2a), ascribable to the oceanic evolution, and by an S1 foliation (Fig. 2b) that represents the oldest detectable Alpine fabric (Rebay, Spalla \& Zanoni, 2012; Zanoni, Rebay \& Spalla, 2016). S1 foliation and up to millimetre-sized oceanic relicts are also preserved in rodingites (Zanoni, Rebay \& Spalla, 2016). S2 is post-dated by localized ductile shear zones and by two groups of folds, represented by tight folds with westdipping axial plane and a $\mathrm{N}-\mathrm{S}$ shallow plunging axis (D3, Fig. 2d) and by open to gentle upright folds with shallow axis (D4), respectively. Among these latter two folding stages, the first is associated with the development of a differentiated axial plane foliation S3 that in serpentinites is marked by a mineral assemblage indicating low-pressure metamorphic conditions, representing the retrograde metamorphic re-equilibration during uplift (Rebay, Spalla \& Zanoni, 2012).

\section{Microstructures and mineral chemistry}

Serpentinites have been divided into two groups on the basis of D2 parageneses - Ti-clinohumitebearing and eclogite facies serpentinite - described in detail by Rebay, Spalla \& Zanoni (2012). PreD2 minerals are represented by porphyroclasts of olivine1, clinopyroxene1 and Ti-clinohumite1 that are wrapped by S2 foliation (Fig. 3a). New mineral growths occur at the rims of clinopyroxene, Ti-clinohumite and olivine as fringes elongated parallel to S2 (Fig. 3a, b). The parageneses associated with D2 consist of olivine2, clinopyroxene2, antigorite \pm Ti-clinohumite $2 \pm$ chlorite \pm zircon

(Fig. 3a, b), whereas post-D2 foliation is defined by serpentine, chlorite \pm amphibole (Fig. 3c). A sample of eclogite facies serpentinite, collected north of Rayes de Proz (star in Fig. 1c), is characterized by pervasive $\mathrm{S} 2$ foliation, wrapping around clinopyroxene porphyroclasts (Fig. 3d-f) and relationships between mineral growth and S2 development are similar to those described above. Two generations of zircon (namely zircon1 and zircon2) are easily recognizable where pre-D2 cores consist of porphyroclasts rimmed by syn-D2 fringe-like overgrowths, aligned along S2 foliation (Fig. 3g). This texture is consistent with that of clinopyroxene, Ti-clinohumite and olivine from all serpentinite types (Fig. 3h). Larger zircon grains are at times boudinaged (Fig. 3i).

Compositions of olivine and clinopyroxene associated with pre-D2 and syn-D2 assemblages are different and distinctive, as detailed in Rebay, Spalla \& Zanoni (2012). In summary, olivine cores and rims are very similar in composition, with a slight decrease in $\mathrm{Mg}$ towards the rims.

Clinopyroxene cores are Al- (up to $0.3 \mathrm{apfu}$ ), Tiand Cr-rich and Ca-poor (0.8-0.92 apfu), whereas synD2 rims are Ca-rich (0.94-1 apfu) and Ti-, Cr- and Al-poor.

Syn-D2 serpentine has higher $\mathrm{Mg}$ (up to $11.45 \mathrm{apfu}$ ) and lower Fe (up to 0.9 apfu) and $\mathrm{Al}$ (up to $0.8 \mathrm{apfu}$ ) contents than pre-D2 serpentine. Based on the majorelement compositional variations, using classical geothermobarometry and thermodynamic modelling, $2.5 \pm 0.3 \mathrm{GPa}$ and $600 \pm 20^{\circ} \mathrm{C}$ were estimated for the formation of mineral parageneses associated with D2 deformation stage (Rebay, Spalla \& Zanoni, 2012). 

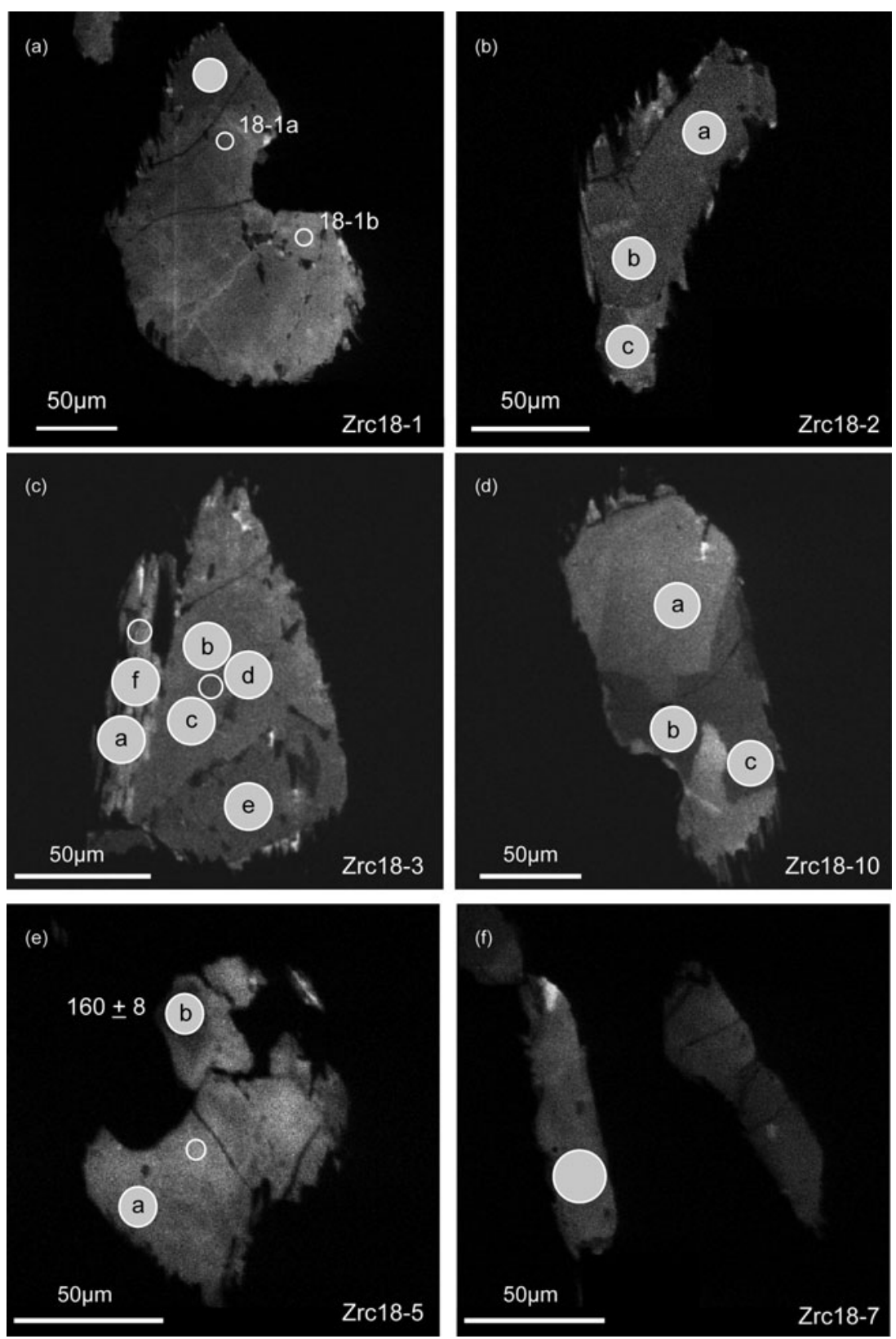

Figure 5. SEM images of zircon grains. (a-c) CL image of homogeneous zircon core with fringe-like syn-D2 overgrowth; (d) CL images of zircon grains showing sector and/or broad-banding zoning within cores and narrow rims with fringe-like syn-D2 overgrowth; $(e, f) C L$ image of homogeneous zircon core with very few and tiny syn-S2 overgrowths; and $(\mathrm{g}-\mathrm{j}, \mathrm{k}-\mathrm{m}) \mathrm{CL}$ images of zircon grains showing sector and/or broad-banding zoning within cores and narrow rims with fringe-like syn-D2 overgrowth. Each image has the name of the zircon indicated and the large shaded circles indicate the spot analysed for $\mathrm{U}-\mathrm{Th}-\mathrm{Pb}$ geochronology, whereas smaller empty circles indicate spots analysed for trace elements. Letters differentiate circles in the same zircon, and correspond to the analyses in Tables 2 and 3. The concordant age of $168 \pm 8$ Ma obtained for zircon 18-5 spot b is also indicated in (e).

Clinopyroxene and zircon cores were analysed for trace-element composition with laser ablation (LA) ICP-MS (Table 2) at the CNR-IGG UOS of Pavia. The instrument couples a Nd:YAG laser working at $266 \mathrm{~nm}$ with a quadrupole ICP-MS (Perkin Elmer DRCe). All analyses were carried out using a $10 \mu \mathrm{m}$ spot (see online supplementary material, available at http://journals.cambridge.org/geo, for details on the analytical method).

The chondrite-normalized rare Earth element (REE) pattern (Fig. 4) of clinopyroxene is characterized by flat heavy REE (at about 100 times CI chondrite), a weak light REE depletion and negative Eu anomaly. $\mathrm{Zr}$ and $\mathrm{Y}$ concentrations are relatively high and are in the ranges $93.3-118 \mathrm{ppm}$ and $402-449 \mathrm{ppm}$. The trace-element composition of zircon cores is characterized by low U concentration (9-18 ppm) and a chondrite-normalized REE pattern typical of growth under magmatic conditions, characterized by light REE depletion, positive Ce anomaly and heavy REE (HREE) enrichment (up to 3000 times CI chondrite). Zircon REE patterns parallel that of clinopyroxene for the occurrence of a negative Eu anomaly. Zircon fringe dimensions allowed only a single analysis. 

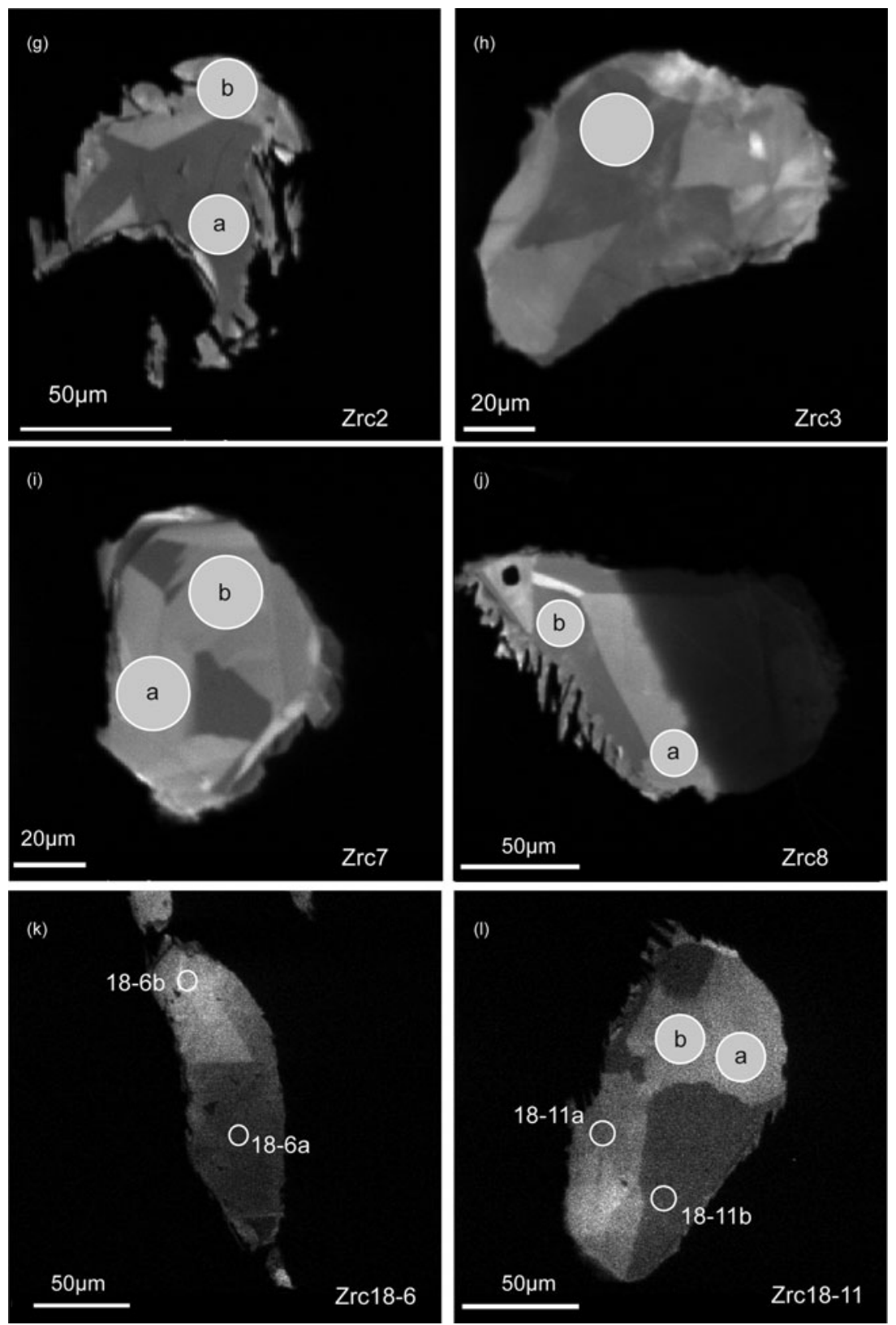

Figure 5. Continued

Trace-element composition of zircon fringes matches that of magmatic cores, revealing no significant difference in both REE contents and Th/U ratios. The absence of garnet and other mineral phases with high compatibility for REE (and other trace elements) in the HP-UHP mineral paragenesis in these rocks prevents their redistribution during zircon recrystallization, and accounts for the similar concentrations between magmatic cores and metamorphic rims.

\section{U-Pb zircon geochronology}

\section{5.a. Method}

$\mathrm{U}-\mathrm{Pb}$ zircon geochronology was carried out with LAICP-MS on polished thin-sections at the CNR-IGG UOS of Pavia. The system couples an ArF excimer laser microprobe (type GeoLas102 from MicroLas) with a sector field ICP-MS (type Element from ThermoFinnigan). The signal of ${ }^{202} \mathrm{Hg},{ }^{204}(\mathrm{~Pb}+\mathrm{Hg}),{ }^{206} \mathrm{~Pb}$, ${ }^{207} \mathrm{~Pb},{ }^{208} \mathrm{~Pb},{ }^{232} \mathrm{Th}$ and ${ }^{238} \mathrm{U}$ masses were acquired. ${ }^{202} \mathrm{Hg}$ is acquired to correct the isobaric interference of ${ }^{204} \mathrm{Hg}$ on ${ }^{204} \mathrm{~Pb}$, so that the common $\mathrm{Pb}$ in the sample can be monitored. The relatively high background at mass 204, due to trace of $\mathrm{Hg}$ in the $\mathrm{He}$ gas, prevents small amounts of common $\mathrm{Pb}$ being detected, however. Remarkably, in the investigated samples the signal of ${ }^{204}(\mathrm{~Pb}+\mathrm{Hg})$ was always indistinguishable from the background and therefore no common $\mathrm{Pb}$ correction was applied. The ${ }^{235} \mathrm{U}$ signal is calculated from ${ }^{238} \mathrm{U}$ on the basis of the ratio ${ }^{238} \mathrm{U} /{ }^{235} \mathrm{U}=137.818$ (Hiess et al. 2012).

Laser-induced $\mathrm{U}-\mathrm{Pb}$ fractionation and mass discrimination effects were simultaneously corrected 
Table 3. Zircon isotopic data and apparent ages (zircon numbers refer to Fig. 5)

\begin{tabular}{|c|c|c|c|c|c|c|c|c|c|c|c|c|c|c|}
\hline \multirow[b]{2}{*}{ Identifier } & \multirow[b]{2}{*}{$\mathrm{Zrc \#}$} & \multirow{2}{*}{\multicolumn{2}{|c|}{ Position }} & \multicolumn{7}{|c|}{ Isotope ratios } & \multicolumn{4}{|c|}{ Apparent ages } \\
\hline & & & & $\mathrm{Cl}$ & ${ }^{207} \mathrm{~Pb} /{ }^{206} \mathrm{~Pb}$ & $2 \sigma$ & ${ }^{207} \mathrm{~Pb} /{ }^{235} \mathrm{U}$ & $2 \sigma$ & ${ }^{206} \mathrm{~Pb} /{ }^{238} \mathrm{U}$ & $2 \sigma$ & ${ }^{207} \mathrm{~Pb} /{ }^{235} \mathrm{U}$ & $2 \sigma$ & ${ }^{206} \mathrm{~Pb} /{ }^{238} \mathrm{U}$ & $2 \sigma$ \\
\hline Ju24a005 & $18-5$ & $\mathrm{a}$ & Core & Bright & 0.0701 & 0.0135 & 0.2570 & 0.0485 & 0.0266 & 0.0013 & 232 & 44 & 169 & 9 \\
\hline Ju24a006 & $18-1$ & & Core & Dark & 0.1071 & 0.0226 & 0.3947 & 0.0803 & 0.0267 & 0.0017 & 338 & 69 & 170 & 11 \\
\hline $\mathrm{Ju} 24 \mathrm{a} 007$ & $18-2$ & $\mathrm{a}$ & Rim & Dark & 0.1526 & 0.0180 & 0.5925 & 0.0669 & 0.0282 & 0.0013 & 472 & 53 & 179 & 8 \\
\hline Ju24a008 & $18-2$ & $\mathrm{~b}$ & Core & Dark & 0.0962 & 0.0300 & 0.3422 & 0.1032 & 0.0258 & 0.0022 & 299 & 90 & 164 & 14 \\
\hline Ju24a009 & $18-2$ & $\mathrm{c}$ & Core & Bright/dark & 0.1841 & 0.0423 & 0.7581 & 0.1621 & 0.0299 & 0.0028 & 573 & 122 & 190 & 18 \\
\hline Ju24a010 & $18-3$ & $\mathrm{a}$ & Rim & Bright & 0.4551 & 0.1359 & 0.6044 & 0.1484 & 0.0096 & 0.0017 & 480 & 118 & 62 & 11 \\
\hline Ju24a011 & $18-3$ & $\mathrm{~b}$ & Rim & Bright & 0.1695 & 0.0744 & 0.2486 & 0.1020 & 0.0107 & 0.0017 & 225 & 93 & 68 & 11 \\
\hline Ju24a012 & $18-3$ & c & Core & Bright/dark & 0.1036 & 0.0161 & 0.3635 & 0.0549 & 0.0255 & 0.0012 & 315 & 48 & 162 & 8 \\
\hline Ju24a013 & $18-3$ & $\mathrm{~d}$ & Core & Dark & 0.0954 & 0.0152 & 0.3461 & 0.0539 & 0.0263 & 0.0013 & 302 & 47 & 167 & 8 \\
\hline Ju24a014 & $18-3$ & $\mathrm{e}$ & Rim & Dark & 0.1080 & 0.0248 & 0.4011 & 0.0889 & 0.0269 & 0.0019 & 342 & 76 & 171 & 12 \\
\hline Ju24a015 & $18-10$ & $\mathrm{a}$ & Core & Bright & 0.0860 & 0.0231 & 0.3300 & 0.0859 & 0.0279 & 0.0022 & 290 & 75 & 177 & 14 \\
\hline Ju24a016 & $18-10$ & $\mathrm{~b}$ & Core & Dark & 0.0523 & 0.0090 & 0.1914 & 0.0326 & 0.0266 & 0.0012 & 178 & 30 & 169 & 8 \\
\hline Ju24a017 & $18-10$ & c & Core & Dark & 0.1132 & 0.0251 & 0.4214 & 0.0893 & 0.0270 & 0.0020 & 357 & 76 & 172 & 13 \\
\hline Ju24a022 & $18-11$ & a & Core & Bright & 0.1276 & 0.0268 & 0.4782 & 0.0957 & 0.0272 & 0.0020 & 397 & 79 & 173 & 13 \\
\hline Ju24a023 & $18-11$ & $\mathrm{~b}$ & Core & Bright & 0.1099 & 0.0197 & 0.4097 & 0.0709 & 0.0270 & 0.0016 & 349 & 60 & 172 & 10 \\
\hline Ju24a024 & 8 & $\mathrm{a}$ & Core & Brigth & 0.0881 & 0.0132 & 0.3323 & 0.0486 & 0.0274 & 0.0013 & 291 & 43 & 174 & 8 \\
\hline Ju24a025 & 8 & $\mathrm{~b}$ & Core & Dark & 0.2311 & 0.0641 & 0.9054 & 0.2293 & 0.0285 & 0.0035 & 655 & 166 & 181 & 22 \\
\hline Ju24a026 & 3 & & Core & Dark & 0.2431 & 0.0328 & 1.0193 & 0.1259 & 0.0304 & 0.0020 & 714 & 88 & 193 & 13 \\
\hline $\mathrm{Ju} 24 \mathrm{a} 027$ & 2 & $\mathrm{a}$ & Core & Dark & 0.2108 & 0.0398 & 0.3116 & 0.0544 & 0.0107 & 0.0009 & 275 & 48 & 69 & 6 \\
\hline $\mathrm{Ju} 24 \mathrm{a} 028$ & 7 & $\mathrm{a}$ & Core & Bright & 0.1510 & 0.0271 & 0.6015 & 0.1025 & 0.0289 & 0.0019 & 478 & 81 & 184 & 12 \\
\hline $\mathrm{Ju} 24 \mathrm{a} 029$ & 7 & $\mathrm{~b}$ & Core & Bright & 0.0477 & 0.0180 & 0.1853 & 0.0690 & 0.0282 & 0.0020 & 173 & 64 & 179 & 13 \\
\hline $\mathrm{Ju} 24 \mathrm{a} 034$ & 2 & $\mathrm{~b}$ & Rim & Bright & 0.0494 & 0.0591 & 0.0679 & 0.0808 & 0.0100 & 0.0013 & 64 & 79 & 67 & 9 \\
\hline Ju24a035 & $18-3$ & $\mathrm{f}$ & Rim & Bright & 0.0460 & 0.0597 & 0.0657 & 0.0851 & 0.0104 & 0.0012 & 67 & 84 & 65 & 8 \\
\hline $\mathrm{Ju} 24 \mathrm{a} 036$ & $18-5$ & $\mathrm{~b}$ & Rim & Dark & 0.0489 & 0.0105 & 0.1707 & 0.0361 & 0.0253 & 0.0013 & 161 & 34 & 160 & 8 \\
\hline Ju24a037 & $18-7$ & & Rim & Dark & 0.0540 & 0.0279 & 0.1860 & 0.0956 & 0.0250 & 0.0015 & 159 & 89 & 173 & 9 \\
\hline
\end{tabular}



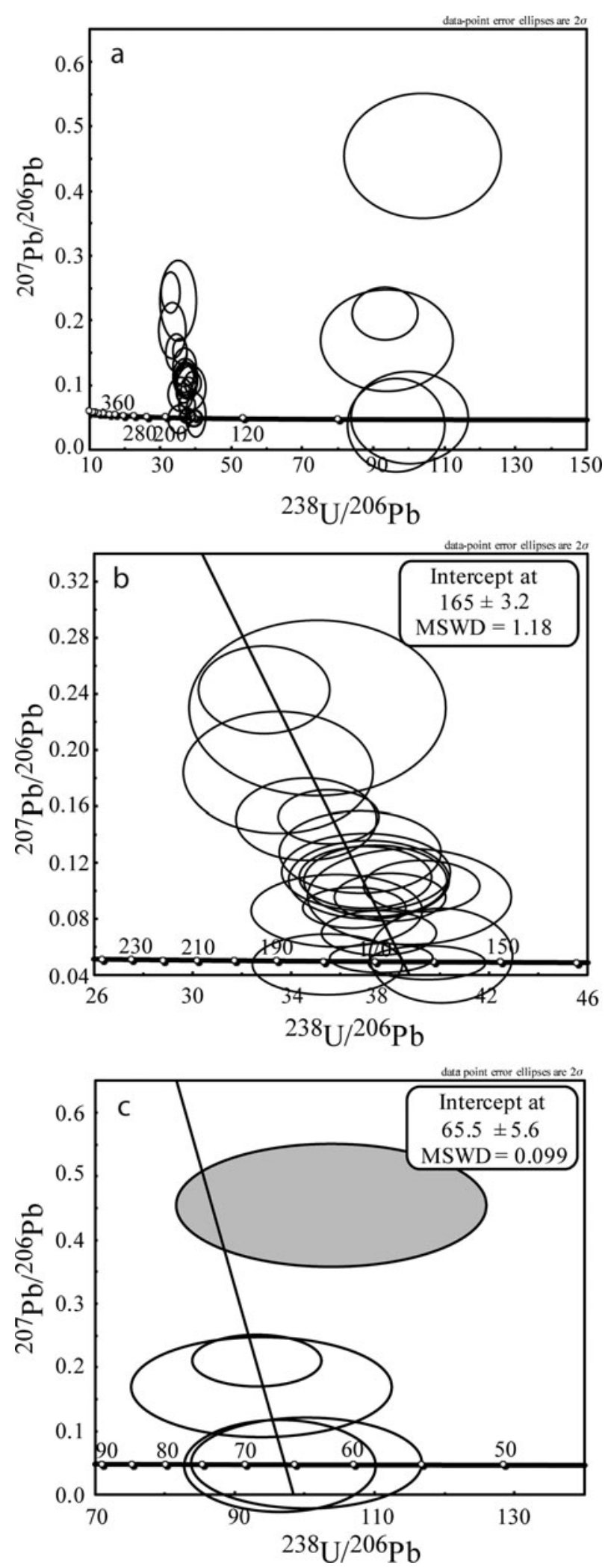

Figure 6. Tera-Wasserburg diagrams of isotopic ratios obtained from (a) all analysed zircon, (b) zircon cores and (c) syn-D2 overgrowths.

using a matrix-matched external standard and considering the same integration intervals on the standard and the unknowns. Analyses were carried out using a spot size of $20 \mu \mathrm{m}$ and a laser fluence of $8 \mathrm{~J} \mathrm{~cm}^{-2}$. The reference zircon GJ-1 (Jackson et al. 2004) was adopted as external standard and the reference zircons
91500 (Wiedenbeck et al. 1995) and 02123 (Ketchum et al. 2001) were selected as validation standards. Data reduction was carried out with the software package GLITTER ${ }^{\circledR}$ (van Achterbergh et al. 2001). Individual uncertainties given by the software for the isotope ratios were propagated relative to the respective reproducibility of the standard. This procedure was carried out for each analytical run as reported in Horstwood et al. (2003). ISOPLOT/Ex 3.00 software package by Ludwig (2003) was used for U-Pb apparent age calculations and representations. Data for external standards and validation standards are reported in online Supplementary Table S1 (available at http://journals.cambridge.org/geo).

\section{5.b. Results}

Zircon grains are generally prismatic and with dimensions up to $100 \mu \mathrm{m}$ in length. They occur as porphyroclasts re-oriented parallel to S2 foliation. Zircon cores show mainly sector and broad banding zoning (Fig. $5 \mathrm{~d}$, g-1); homogeneous inner domains are also common (e.g. Fig. 5a-c, e-f). A peculiar feature, recognizable at the optical microscope (Fig. 3g) and well visible with CL imaging, is fringe-like tiny overgrowths elongated in the S2 HP-UHP foliation (Fig. 5a-d, g, j-1). Fringes are completely new portions of zircon without intergrowths with magmatic domains. Since the fringes are a few dozen microns in size, only those large enough to contain the spot were analysed. This selection avoided mixing rims with the inner (and older) cores, as confirmed by the consistency of the results and detailed in Figure 5, where the position of analyses is reported. Large zircons are frequently boudinaged (Fig. 3i); if zircon grains are separated into two or more fragments a narrow rim surrounds the different portions and is locally characterized by fringes parallel to S2 foliation, suggesting that boudinaging was coeval with the formation of these overgrowths (e.g. Fig. 5).

Eleven zircon grains were selected for analysis and $23 \mathrm{U}-\mathrm{Pb}$ data were collected. Isotopic ratios (Table 3) define two main arrays on the Tera-Wasserburg diagram (Fig. 6a). According to Compston (1999) the lower intercept of the array should fix the crystallization age, whereas the upper intercept defines the common $\mathrm{Pb}$ composition. The major cluster is from zircon cores and yields a lower intercept age at $165 \pm 3.2 \mathrm{Ma}$ (Fig. 6b). The minor cluster (four analyses) is from the tiny overgrowths and yields a lower intercept age at $65.5 \pm 5.6 \mathrm{Ma}$ (Fig. 6c).

\section{Pressure-temperature-deformation-time $(\boldsymbol{P}-\boldsymbol{T}-\boldsymbol{d}-\boldsymbol{t})$ evolution and discussion}

Textural features, mineral compositions and $\mathrm{U}-\mathrm{Pb}$ geochronology allow additional constrains to be imposed on the two evolution steps witnessed by the ZSZ serpentinites and detailed in Rebay, Spalla \& Zanoni (2012). 
(a)

(b)
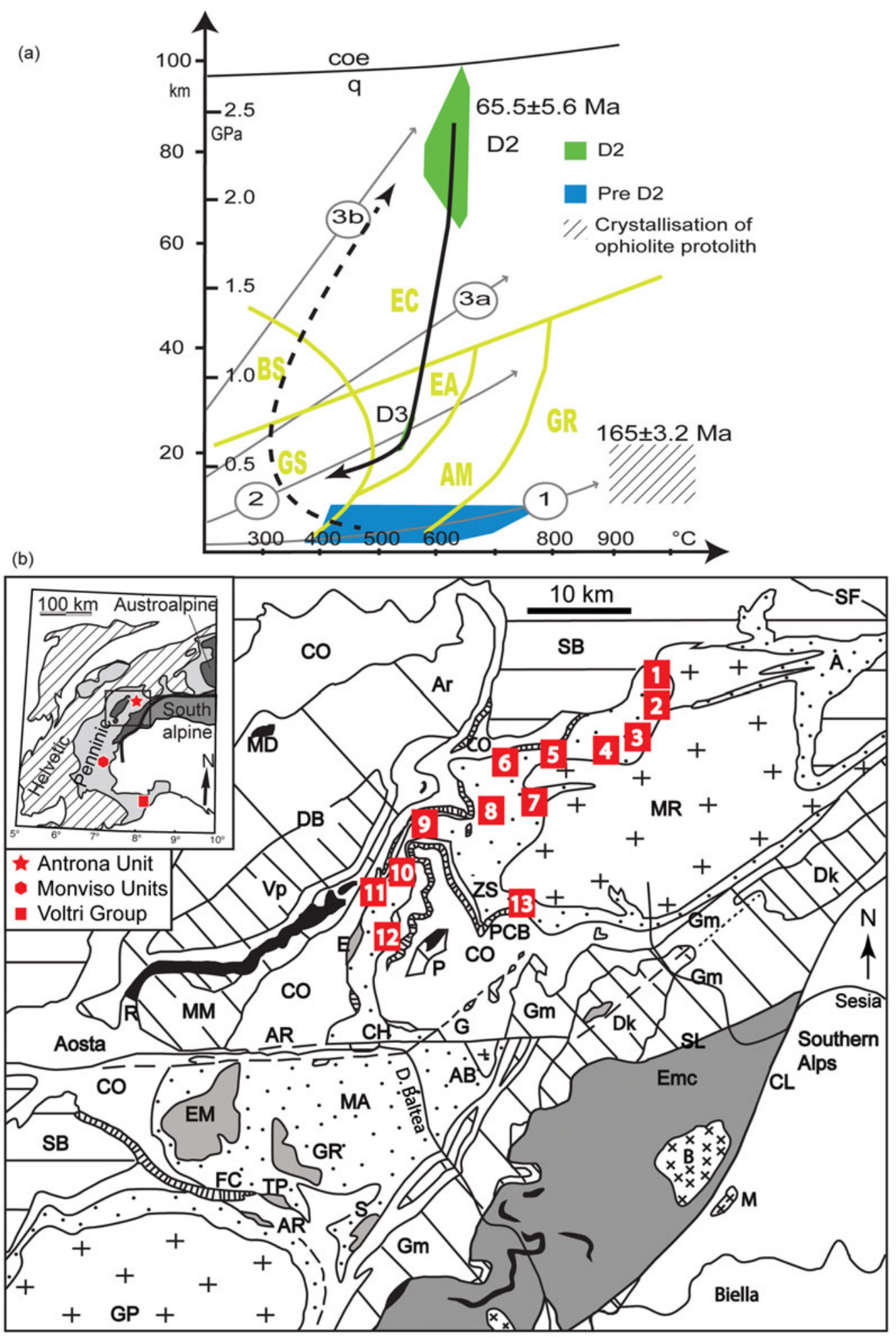

Figure 7. (Colour online) (a) $P-T-d-t$ evolution of the studied ZSZ rocks synthesized from Rebay, Spalla \& Zanoni (2012) and Zanoni, Rebay \& Spalla (2016). Metamorphic facies are after Spear (1993). GS - greenschist; BS - blueschist; EC - eclogite; EA epidote-amphibolite; AM - amphibolite; GR - granulite. Geotherms after Cloos (1993): (1) near spreading ridge or volcanic arc; (2) normal gradient of old plate interior; (3a) warm subduction zones; and (3b) cold subduction zones. (b) Tectonic sketch map of the northwestern Alps with the location of dated samples in the ZSZ. The inset shows the Western Alps with location of dated samples at Monviso. Nappe systems: Penninic continental nappe (MR - Monte Rosa; AB - Arcesa-Brusson; GP - Gran Paradiso; SB - Gran St Bernard); Austroalpine nappe (DB - Dent Blanche; MM - Mont Mary; P - Pillonet; AR - Acque Rosse; CH - Chatillon-St Vincent; E - Etirol-Levaz; G - Grun; EM - Mt Emilius; GR - Glacier-Refray; S - Santanel; TP - Tour Ponton; SL - Sesia-Lanzo Zone; Vp - Valpelline series; Dk - Diorite-kinzigitic series, Ar - Arolla series; Gm1 - Gneiss Minuti Complex, non-eclogitic; Gm2 - Gneiss Minuti Complex, with eclogitic relicts; Emc - Eclogitic Micashist Complex; Mesozoic metasedimentary cover (black): R - Roisan Zone); and Ophiolite Piedmont Zone (CO - Combin Zone; PCB - Pancherot-Cime Bianche; FC - Faisceau de Cogne; ZS - ZermattSaas; MA - Mt Avic; A - Antrona ophiolite). Tectonic lines: CL - Canavese tectonic line; AR - Aosta-Ranzola fault system; SF Simplon normal fault; MD - Mont Dolent; B - Biella; M - Miagliano; SC - Redrawn after Dal Piaz (1999). 
Cores of the clinopyroxene and zircon porphyroclasts yield information on the protolith and more in general on the magmatic stage. The primary mineralogy of the rock is not preserved, so the identification of the rock type is not straightforward. Nonetheless, the negative $\mathrm{Eu}$ anomaly in both clinopyroxene and zircon (Fig. 4) suggests that the equilibrium melt already crystallized plagioclase. The abundant zircon and the relatively high concentrations of incompatible elements, such as $\mathrm{Zr}$ and $\mathrm{Y}$, also suggest that the equilibrium melt was relatively evolved and not basaltic. Support for this conclusion is provided by the similar trace-element composition of analysed clinopyroxene as those from evolved lithologies of the Alpine Thetys such as the Fe-Ti oxide diorites (Tiepolo, Tribuzio \& Vannucci, 1997). Textural and chemical features of zircon and clinopyroxene coupled to the overall mineralogy of the rock (olivine/serpentine-dominated) suggest that the evolved melt likely percolated/intruded the lithospheric mantle. The occurrence of gabbro bodies and rodingite dykes nearby support this conclusion. Processes of melt percolation and melt-rock reaction between the oceanic lithospheric mantle and melts with MORB affinity are well documented in both the Lanzo Massif (Piccardo, Zanetti \& Müntener, 2007; Piccardo et al. 2007) and the Ligurian ophiolites (Sanfilippo, Tribuzio \& Tiepolo, 2014). U-Pb geochronology yields a date of $165 \pm 3.2 \mathrm{Ma}$ for the zircon cores. Regarding mantle rocks, this date can either constrain the age of injection of the MORB-type melt into the mantle or the age of cooling of the oceanic lithosphere as a consequence of exhumation. Notwithstanding, the Middle Jurassic age is in perfect agreement with current knowledge on the age of formation of the Tethyan oceanic lithosphere in the Alps and Apennines (Rubatto, Gebauer \& Fanning, 1998; Marotta et al. 2016; Tribuzio et al. 2016).

Both clinopyroxene and zircon porphyroclasts have rims and fringes parallel to the $\mathrm{S} 2$ foliation at the strain cap and shadow, respectively, which crystallized at $P-T$ conditions of $2.2-2.8 \mathrm{GPa}$ and $580-620^{\circ} \mathrm{C}(\mathrm{Re}-$ bay, Spalla \& Zanoni, 2012). The new U-Pb data reveal that this HP-UHP event, registered by the recrystallization of zircon rims and fringes at these $P-T$ conditions, likely occurred at $65.5 \pm 5.6 \mathrm{Ma}$ and was followed by syn-D3 re-equilibration under epidoteamphibolite facies conditions (Fig. 7a; Rebay, Spalla \& Zanoni, 2012; Zanoni, Rebay \& Spalla, 2016). Radiometric ages obtained in this work extend the range 35-52 Ma reported in the literature for the Alpine HP-UHP re-equilibration towards older ages (Fig. 7b; Table 1). Remarkably, most of the literature ages have been obtained from samples that are within $20 \mathrm{~km}$ of the investigated area, and some are even nearer $(\leq 5 \mathrm{~km})$. Such geochronological heterogeneities imply that some sections of the ZSZ have likely experienced HP-UHP metamorphism earlier than previously thought; this supports the interpretation, based on contrasted $P-T$ evolutions, that ZSZ is a complex containing different tectono-metamorphic units (e.g. Re- bay, Spalla \& Zanoni, 2012; Weber \& Bucher, 2015). The new ages are comparable to those already reported for the HP re-equilibration in the subducted continental crust of the Sesia-Lanzo Zone, which records the oldest subduction ages among the tectonic units of the Western Alps (Rubatto, Gebauer \& Compagnoni, 1999; Handy \& Oberhänsli, 2004; Meda, Marotta \& Spalla, 2010; Spalla et al. 2010; Cenki-Tok et al. 2011; Rubatto et al. 2011; Roda, Spalla \& Marotta, 2012). Similar ages were also reported for the continental inliers of ZSZ (Beltrando, Rubatto \& Manatschal, 2010; Weber et al. 2015; Fassmer et al. 2016).

Older ages interpreted as dating the $P-T$ prograde evolution (Table 1; Skora et al. 2009, 2015) indicate that the subduction of ZSZ oceanic slices was already active at $80 \mathrm{Ma}$. Our data are therefore coherent with oceanic lithosphere subduction, necessary to justify the low thermal regime under which Western Alpine continental crust was exhumed (e.g. Zucali, Spalla \& Gosso, 2002; Roda, Spalla \& Marotta, 2012).

Scattered peak ages (41-72 Ma; Cliff, Barnicoat \& Inger, 1998; Table 1) are also observed in the Monviso Massif, supporting the interpretation that it represents a complex of ophiolitic HP slices accreted during the final stages of their exhumation (Schwartz et al. 2000; Guillot et al. 2004). The detection of contrasted petrologic and chronologic histories in both the ZSZ and Monviso Massif confirms that the HP metaophiolites of Piedmont zone is a highly heterogeneous domain composed of slices of variable size, from one to tens of kilometres $^{3}$ (e.g. Guillot et al. 2004).

\section{Conclusions}

In summary, our results allow us to demonstrate that multiscale structural analysis assisted by detailed thermodynamic modelling is a fundamental tool for dating single deformation stages and associated mineral transformations.

The results confirm a Middle Jurassic age for oceanic crust accretion, which is in agreement with that observed in the ophiolitic complexes from the Alps and Apennines.

Finally, our results allow us to widen the time span under which rocks of ZSZ recorded HP-UHP conditions during 70-38 Ma and to infer that syn-D2 eclogite facies metamorphic imprint developed at $65.5 \pm 5.6 \mathrm{Ma}$ under a very low thermal regime, as suggested by the relationships with geotherm inferred by Cloos (1993) for cold subduction zones (Fig. 7). These findings go along with the cold thermal regime under which the Sesia-Lanzo Zone was exhumed, before intrusion of the Periadriatic magmas, which is compatible with ongoing oceanic subduction (e.g. Zucali, Spalla \& Gosso, 2002; Zanoni, Spalla \& Gosso, 2010; Roda, Spalla \& Marotta, 2012; Roda \& Zanoni, 2016).

Heterogeneous HP-UHP ages and contrasted $P-$ $T-d-t$ evolution within ZSZ can be explained either by: considering slices of ophiolites within a hydrated 
mantle wedge that follow the same path at different times in a subduction system, where they can be tectonically sampled at different depths; or considering that they can follow different paths. These ophiolite slices can be coupled and/or decoupled at different times in a relatively long-lasting subduction system where oceanic and continental lithosphere are involved, as is the case for the Western Alps.

\section{Declaration of interest}

No conflict of interest exists for the authors.

Acknowledgements. G.R., D.Z. and M.I.S. acknowledge funding from MIUR (Ministero dell'Istruzione, dell'Università e della Ricerca) PRIN 2010-2011 (grant number 2010AZR98L) 'Birth and death of oceanic basins: geodynamic processes from rifting to continental collision in Mediterranean and circum-Mediterranean orogens' and G. Gosso, A.M. Marotta and M. Zucali for fruitful discussions on Alpine dynamics. D.Z. and P.L. acknowledge funding from the projects 'Deformazione e metamorfismo delle ofioliti di alta pressione nelle Alpi Occidentali', Università di Pavia and 'Analisi delle impronte strutturali e metamorfiche delle rocce femiche e ultrafemiche della Zona Zermatt-Saas (alta Valtournanche) per la ricostruzione della loro evoluzione geodinamica', Università di Milano, respectively. We wish to thank Gaetano Ortolano, Giovanni Capponi and an anonymous reviewer for useful suggestions and discussions that improved the manuscript.

\section{Supplementary material}

To view supplementary material for this article, please visit http://doi.org/10.1017/S0016756817000334

\section{References}

Amato, J. M., Johnson, C. M., Baumgartner, L. P. \& BEARD, B. L. 1999. Rapid exhumation of the ZermattSaas ophiolite deduced from high precision Sm-Nd and $\mathrm{Rb}$-Sr geochronology. Earth and Planetary Science Letters 171, 425-38.

Angiboust, S. \& Agard, P. 2010. Initial water budget: the key to detaching large volumes of eclogitized oceanic crust along the subduction channel? Lithos 120, 45374.

Angiboust, S., Agard, P., Jolivet, L. \& Beyssac, O. 2009. The Zermatt-Saas ophiolite: the largest (60-km wide) and deepest (c. $70-80 \mathrm{~km}$ ) continuous slice of oceanic lithosphere detached from a subduction zone? Terra Nova 21, 171-80.

Angiboust, S., Langdon, R., Agard, P., Waters, D. \& ChopIN, C. 2012. Eclogitization of the Monviso ophiolite (W. Alps) and implications on subduction dynamics. Journal of Metamorphic Geology 30, 37-61.

ARGAND, E. 1911. Les nappes de recouvrement des Alpes Pennines et leurs prologements structuraux. Matériaux pour la Carte Géologique de la Suisse, n.s. 31, 1-26.

BARNICOAT, A. C. 1988. Zoned high-pressure assemblages in pillow lavas of the Zermatt-Saas ophiolite zone, Switzerland. Lithos 21, 227-36.

BARnicoAT, A. C. \& FrY, N. 1986. High pressure metamorphism of the Zermatt-Saas ophiolite zone, Switzer- land. Journal of the Geolological Society of London 143, 603-18.

Baumann, C., Gerya, T. V. \& Connolly, J. A. D. 2010. Numerical modelling of spontaneous slab-breakoff dynamics during continental collision. In: Advances in Interpretation of Geological Processes: Refinement of Multi-Scale Data and Integration in Numerical Modelling (eds M. I. Spalla, A. M. Marotta \& G. Gosso), pp. 99-114. Geological Society, London, Special Publication no. 332.

BeARTH, P. 1967. Die ophiolite der Zone von Zermatt-Saas Fee. Beitrag Geologische Karte Schweitz 132, 1-130.

Beltrando, M., Rubatto, D. \& Manatschal, G. 2010. From passive margins to orogens: the link between ocean-continent transition zones and (ultra-)highpressure metamorphism. Geology 38(6), 559-62.

Bowtell, S. A., Cliff, R. A. \& Barnicoat, A. C. 1994. $\mathrm{Sm}-\mathrm{Nd}$ isotopic evidence on the age of eclogitization in the Zermatt-Saas ophiolite. Journal of Metamorphic Geology 12, 187-96.

Brongniart, A. 1813. Essai d'une classification minéralogique des roches mélangées. Journal des Mines XXXIV, 190-9.

Bucher, K., Fazis, Y., de Capitani, C. \& Grapes, R. 2005. Blueschists, eclogites, and decompression assemblages of the Zermatt-Saas ophiolite: high-pressure metamorphism of subducted Tethys lithosphere. American Mineralogist 90, 821-35.

Bucher, K. \& Frey, M. 1994. Petrogenesis of Metamorphic Rocks. Heidelberg, Berlin: Springer, 318 pp.

Bucher, K. \& GraPES, R. 2009. The eclogite-facies Allalin gabbro of the Zermatt-Saas ophiolite, Western Alps: a record of subduction zone hydration. Journal of Petro$\log y$ 50, 1405-42.

Caron, J. M., Polino, R., Pognante, U., Lombardo, B., Lardeaux, J. M., Lagabrielle, Y., Gosso, G. \& Allenbach, B. 1984. Ou sont les sutures majeures dans les Alpes internes? (transversale BriançonTorino). Memorie della Società Geologica Italiana $\mathbf{2 9}$, 71-8.

Cartwright, I. \& Barnicoat, A. C. 2002. Petrology, geochronology, and tectonics of shear zones in the ZermattSaas and Combin zones of the Western Alps. Journal of Metamorphic Geology 20, 263-81.

Cenki-Tok, B., Oliot, E., Rubatto, D., Berger, A., Engi, M., Janots, E., Thomsen, T. B., Manzotti, P., Regis, D., Spandler, C., Robyr, M. \& Goncalves, P. 2011. Preservation of Permian allanite within an Alpine eclogite facies shear zone at Mt Mucrone, Italy: mechanical and chemical behavior of allanite during mylonitization. Lithos 125, 40-50.

Chemenda, A. I., Mattauer, M., Malavieille, J. \& Bokun, A. N. 1995. A mechanism for syn-collisional rock exhumation and associated normal faulting: results from physical modelling. Earth and Planetary Science Letters 132, 225-32.

Chinner, G. A. \& Dixon, J. E. 1973. Some high pressure parageneses of the Allalin gabbro, Valis, Switzerland. Journal of Petrology 14, 185-202.

Cliff, R. A., BarnicoAt, A. C. \& Inger, S. 1998. Early Tertiary eclogite facies metamorphism in the Monviso ophiolite. Journal of Metamophic Geology 16, 447-55.

Cloos, M. 1982. Flow melanges: numerical modelling and geological constraints on their origin in the Franciscan subduction complex. Geological Society of America Bulletin 93, 330-45.

Cloos, M. 1993. Lithospheric buoyancy and collisional orogenesis: subduction of oceanic plateaus, continental 
margins, island arcs, spreading ridges, and seamounts. Geological Society of America Bulletin 105, 715-37.

Compston, W. 1999. Geological age by instrumental analysis: the 29th Hallimond Lecture. Mineralogical Magazine 63, 297-311.

Dal PiaZ, G. V. 1974. Le métamorphisme de haute pression et basse température dans l'évolution structurale du bassin ophiolitique alpino-apenninique. Schweizerische Mineralogische und Petrographische Mitteilungen 54, 399-424.

Dal Piaz, G. V. 1999. The Austroalpine-Piedmont nappe stack and the puzzle of Alpine Tethys. In 3rd Workshop on Alpine Geological Studies (eds G. Gosso, F. Jadoul, M. Sella \& M. I. Spalla), pp. 155-76. Societa Cooperativa Tipografica, Padua, Italy, Memorie di Scienze Geologiche.

DAl PiAz, G. V. 2010. The Italian Alps: a journey across two centuries of Alpine geology. Journal of the Virtual Explorer 36, paper 8, 1-108.

Dal Piaz, G. V., Cortiana, G., Del Moro, A., Martin, S., Pennacchioni, G. \& Tartarotti, P. 2001. Tertiary age and paleostructural inferences of the eclogitic imprint in the Austroalpine outliers and Zermatt-Saas Zone ophiolite, western Alps. International Journal of Earth Sciences 90, 668-84.

Dal Piaz, G. V. \& Ernst, W. G. 1978. Areal geology and petrology of eclogites and associated metabasites of the Piemonte ophiolite nappe, Breuil - St. Jacques area, Italian Western Alps. Tectonophysics 51, 99-126.

Dal Piaz, G. V., Venturelli, G., Spadea, P. \& Di BatTISTINI, G. 1981. Geochemical features of metabasalts and metagabbros from the Piemonte ophiolite nappe, Italian Western Alps. Neues Jahrbuch für Mineralogie - Abhandlungen 142, 248-69.

Dale, C. W., Burton, K. W., Pearson, D. G., Gannoun, A., Alard, O., Argles, T. W. \& Parkinson, I. J. 2009. Highly siderophile element behaviour accompanying subduction of oceanic crust: whole rock and mineralscale insights from a high-pressure terrain. Geochimica et Cosmochimica Acta 73, 1394-416.

De Giusti, F., Dal Piaz, G., V., Schiavo, A., Massironi, M., Monopoli, B. \& Bistacchi, A. 2003. Carta geotettonica della Valle d'Aosta. Memorie Di Scienze Geologiche 55, 129-49.

de Meyer, C. M. C., Baumgartner, L. P., Beard, B. L. \& JoHnSON, C. M. 2014. Rb-Sr ages from phengite inclusions in garnets from high pressure rocks of the Swiss Western Alps. Earth and Planetary Science Letters 395, 205-16.

Duchêne, S., Blichert-Toft, J., Luais, B., Télouk, P., Lardeaux, J. M. \& AlbarÈDE, F. 1997. The Lu-Hf dating of garnets and the ages of the Alpine high-pressure metamorphism. Nature 387, 586-9.

Ernst, W. G. \& Dal Piaz, G. V. 1978. Mineral parageneses of eclogitic rocks and related mafic schists of the Piemonte ophiolite nappe, Breuil-St Jacques area, Italian Western Alps. American Mineralogist 63, 62140.

Fassmer, K., Obermul̈ler, G., Nagel, T. J., Kirst, F., Froitzheim, N., Sandmann, S., Miladinova, I., Fonseca, R. O. C. \& Mü̈Ker, C. 2016. Highpressure metamorphic age and significance of eclogite-facies continental fragments associated with oceanic lithosphere in the Western Alps (EtirolLevaz Slice, Valtournenche, Italy). Lithos 252, 145-59, doi:10.1016/j.lithos.2016.02.019.

Federico, L., Capponi, G., Crispini, L., Scambelluri, M. \& VilLA, I. M. 2005. ${ }^{39} \mathrm{Ar} /{ }^{40} \mathrm{Ar}$ dating of high-pressure rocks from the Ligurian Alps: evidence for a continuous subduction-exhumation cycle. Earth and Planetary Science Letters 240(3), 668-80.

Frezzotti, M. L., Selverstone, J., Sharp, Z. D. \& Compagnoni, R. 2011. Carbonate dissolution during subduction revealed by diamond-bearing rocks from the Alps. Nature Geoscience 4, 703-6.

GerYA, T. V. 2011. Future directions in subduction modelling. Journal of Geodynamics 52, 344-78.

Gouzu, C., Itaya, T., Hyodo, H. \& Matsuda, T. 2006. Excess 40Ar-free phengite in ultrahigh-pressure metamorphic rocks from the Lago di Cignana area, Western Alps. Lithos 92(3-4), 418-30.

Gouzu, C., Yagi, K., Thanh, N. X., Itaya, T. \& Compagnoni, R. 2016. White mica K-Ar geochronology of HP-UHP units in the Lago di Cignana area, western Alps, Italy: tectonic implications for exhumation. Lithos 248, 109-18.

Groppo, C., Beltrando, M. \& Compagnoni, R. 2009. The $\mathrm{P}-\mathrm{T}$ path of the ultra-high pressure Lago Di Cignana and adjoining high-pressure meta-ophiolitic units: insights into the evolution of the subducting Tethyan slab. Journal of Metamorphic Geology 27, 207-31.

Guillot, S., Schwartz, S., Hattori, K., Auzende, A. \& Lardeaux, J. M. 2004. The Monviso ophiolitic massif (Western Alps), a section through a serpentinite subduction channel. Journal of the Virtual Explorer 16, paper $3,1-16$.

HANDY, M. R. \& ObERHÄNSLI, R. 2004. Explanatory notes to the map: metamorphic structures of the Alps age map of the metamorphic structure of the Alps - tectonic interpretation and outstanding problems. Mitteilungen Österreichische Mineralogische Gesellschaft 149, 201-25.

Herwartz, D., Münker, C., Scherer, E. E., Nagel, T. J., Pleuger, J. \& Froitzheim, N. 2008. Lu-Hf garnet geochronology of eclogites from the Balma Unit (Pennine Alps): implications for Alpine paleotectonic reconstructions. Swiss Journal of Geosciences 101(S1), 173-89.

Hiess, J., Condon, D. J., McLean, N. \& Noble, S. R. 2012. ${ }^{238} \mathrm{U} /{ }^{235} \mathrm{U}$ systematics in terrestrial Uranium-bearing minerals. Geology 335, 1610-14.

Horstwood, M. S. A., Foster, G. L., Parrish, R. R., Noble, S. R. \& Nowell, G. M. 2003. Common-Pb corrected in situ U-Pb accessory mineral geochronology by LA-MC-CP-MS. Journal of Analytical Atomic Spectrometry 18, 837-46.

Jackson, S. E., Pearson, N. J., Griffin, W. L. \& Belousova, E. 2004. The application of laser ablation inductively coupled plasma mass spectrometry to in situ U-Pb zircon geochronology. Chemical Geology 211, 47-69.

Ketchum, J. W. F., Jackson, S. E., Culshaw, N. G. \& BARR, S. M. 2001. Depositional and tectonic setting of the Paleoproterozoic Lower Aillik Group, Makkovik Province, Canada: evolution of a passive marginforedeep sequence based on petrochemistry and U$\mathrm{Pb}$ (TIMS and LAM-ICP-MS) geochronology. Precambrian Research 105, 331-56.

Lapen, T. J., Johnson, C. M., Baumgartner, L. P., Mahlen, N. J., Beard, B. L. \& Amato, J. M. 2003. Burial rates during prograde metamorphism of ultrahigh-pressure terrane: an example from Lago di Cignana, Western Alps, Italy. Earth and Planetary Science Letters 215, 57-72.

Li, X. P., Rahn, M. K. \& Bucher, K. 2004. Serpentinites of the Zermatt-Saas ophiolite complex and their 
texture evolution. Journal of Metamorphic Geology 22, $159-77$.

Liati, A., Froitzheim, N. \& Fanning, C. M. 2005. Jurassic ophiolites within the Valais domain of the Western and Central Alps: geochronological evidence for re-rifting of oceanic crust. Contributions to Mineralogy and Petrology 149(4), 446-61.

Lombardo, B., Rubatto, D. \& Castelli, D. 2002. Ion microprobe $\mathrm{U}-\mathrm{Pb}$ dating of zircon from a Monviso metaplagiogranite: implications for the evolution of the Piedmont-Liguria Tethys in the Western Alps. Ofioliti 27(2), 109-17.

LUDWIG, K. R. 2003. Isoplot/Ex version 3.0: a geochronological toolkit for Microsoft Excel. Berkeley Geochronology Center Special Publication 4. Berkeley, Berkeley Geochronology Center, 70 pp.

Mahlen, N. J., Johnson, C. M., Baumgartner, L. P., LAPEN, T. J., Skora, S. \& BeARD, B. L. 2006. The protracted subduction history and HP/UHP metamorphism of the Zermatt-Saas ophiolite, western Alps, as constrained by Lu-Hf geochronology. In EOS Transactions AGU Fall Meeting, pp. V41E-05, San Francisco, 11-15 December 2006.

Malatesta, C., Crispini, L., Federico, L., Capponi, G. \& Scambelluri, M. 2012. The exhumation of high pressure ophiolites (Voltri Massif, Western Alps): insights from structural and petrologic data on metagabbro bodies. Tectonophysics 568-9, 102-23.

Malatesta, C., Gerya, T. V., Crispini, L., Federico, L. \& CAPPONI, G. 2016. Interplate deformation at earlystage oblique subduction: 3 -D thermomechanical numerical modelling. Tectonics 35(7), 1610-25, doi: 10.1002/2016TC004139.

Marotta, A. M., Roda, M., Conte, K. \& Spalla, M. I. 2016. Thermo-mechanical numerical model of the transition from continental rifting to oceanic spreading: the case study of the Alpine Tethys. Geological Magazine, published online 3 October 2016, doi: 10.1017/S0016756816000856.

Martin, S., Rebay, G., Kienast, J. R. \& Mevel, C. 2008. An ophiolitic palaeo-hydrothermal field metamorphosed in the eclogite-facies from the Italian western Alps, Saint Marcel valley. Ofioliti 33, 49-63.

Meda, M., Marotta, A. M. \& Spalla, M. I. 2010. The role of mantle hydration in continental crust recycling in the wedge region. In: Advances in Interpretation of Geological Processes: Refinement of Multi-Scale Data and Integration in Numerical Modelling (eds M. I. Spalla, A. M. Marotta \& G. Gosso), pp. 149-72. Geological Society, London, Special Publication no. 332.

MeYer, J. 1983. Mineralogie und Petrologie des Allalingabbros. PhD thesis, Universitat Basel. Published thesis.

Monié, P. \& Philippot, P. 1989. Mise en évidence de l'âge éocène moyen du métamorphisme de haute-pression dans la nappe ophiolitique du Monviso (Alpes occidentales) par la méthode ${ }^{39} \mathrm{Ar}-{ }^{40} \mathrm{Ar}$. Comptes rendus de l'Académie des sciences. Série 2, Mécanique, Physique, Chimie, Sciences de l'univers, Sciences de la Terre 309(2), 245-51.

OBERHÄNSLI, R. 1980. PT bestimmungen anhand von mineralanalysen in eklogiten und glaukophaniten der ophiolite von Zermatt. Schweizerische Mineralogische und Petrographische Mitteilungen 60, 215-35.

Piccardo, G. B., Zanetti, A. \& Müntener, O. 2007. Melt/peridotite interaction in the Southern Lanzo peridotite: Field, textural and geochemical evidence. Lithos 94(1), 181-209.
Piccardo, G. B., Zanetti, A., Pruzzo, A. \& Padovano, M. 2007. The North Lanzo peridotite body (NW Italy): lithospheric mantle percolated by MORB and alkaline melts. Periodico di Mineralogia 76(2-3), 199-221.

Polino, R., Dal Piaz, G. V. \& Gosso, G. 1990. Tectonic erosion at the Adria margin and accretionary processes for the Cretaceous orogeny of the Alps. Mémoires de la Société Géologique de France 156, 345-67.

Rebay, G., Spalla, M. I. \& ZanONI, D. 2012. Interaction of deformation and metamorphism during subduction and exhumation of hydrated oceanic mantle: insights from the Western Alps. Journal of Metamorphic Geology 30, 687-702.

Reddy, S. M., Wheeler, J. \& Cliff, R. A. 1999. The geometry and timing of orogenic extension; an example from the Western Italian Alps. Journal of Metamorphic Geology 17, 573-89.

ReINECKE, T. 1991. Very high pressure metamorphism and uplift of coesite-bearing metasediments from the Zermatt-Saas Zone, Western Alps. European Journal of Mineralogy 10, 7-17.

ReINECKE, T. 1995. Ultrahigh and high-pressure metamorphic rocks of the Zermatt-Saas zone, Western Alpsrecords of burial and exhumation paths. Bochumer Geologische und Geotechnische Arbeiten 44, 152-7.

ReINECKE, T. 1998. Prograde high- to ultrahigh-pressure metamorphism and exhumation of oceanic sediments at Lago di Cignana, Zermatt-Saas zone, western Alps. Lithos 42, 147-89.

RING, U. 1995. Horizontal contraction or horizontal extension? Heterogeneous late Eocene and early Oligocene general shearing during blueschist and greenschist facies metamorphism at the Pennine-Austroalpine boundary zone in the Western Alps. Geologische Rundschau 84, 843-59.

Roda, M., Marotta, A. M. \& Spalla, M. I. 2010. Numerical simulations of an ocean-continent convergent system: influence of subduction geometry and mantle wedge hydration on crustal recycling. Geochemistry, Geophysics, Geosystems 11, 1-21.

Roda, M., Spalla, M. I. \& Marotta, A. M. 2012. Integration of natural data within a numerical model of ablative subduction: a possible interpretation for the Alpine dynamics of the Austroalpine crust. Journal of Metamorphic Geology 30, 973-96.

RoDA, M. \& ZANONI, D. 2016. Testing the thermal state of Biella pluton country rocks via numerical model of magma cooling. In GeoMod 2016 Conference, Montpellier, France, 17-20 October, p. 84-5.

Rubatto, D., Gebauer, D. \& Compagnoni, R. 1999. Dating of eclogite facies zircons: the age of Alpine metamorphism in the Sesia-Lanzo Zone (Western Alps). Earth and Planetary Sciences Letters 167, 141-58.

Rubatto, D., Gebauer, D. \& Fanning, M. 1998. Jurassic formation and Eocene subduction of the Zermatt-SaasFee ophiolites: implications for the geodynamic evolution of the Central and Western Alps. Contributions to Mineralogy and Petrology 132, 269-87.

Rubatto, D., Regis, D., Hermann, J., Boston, K., Engi, M., Beltrando, M. \& McAlpine, S. R. B. 2011. Yo-yo subduction recorded by accessory minerals in the Italian Western Alps. Nature Geoscience 4(5), 338-42.

Rubatto, R. \& HermanN, J. 2003. Zircon formation during fluid circulation in eclogites (Monviso, Western Alps): Implications for $\mathrm{Zr}$ and $\mathrm{Hf}$ budget in subduction zones. Geochimica et Cosmochimica Acta 67, 2173-87.

SAnfilippo, A., TribuZio, R. \& Tiepolo, M. 2014. Mantlecrust interaction in the oceanic lithosphere: constraints 
from minor and trace elements in olivine. Geochimica et Cosmochimica Acta 141, 423-39.

Schwartz, S., Lardeaux, J. M., Guillot, S. \& Tricart, P. 2000. Diversite'du metamorphisme ećlogitique dans le massif ophiolitique du Monviso (Alpes Occidentales, Italie). Geodinamica Acta 13, 169-88.

Skora, S., Lapen, T. J., Baumgartner, L. P., Johnson, C. M., Hellebrand, E. \& Mahlen, N. J. 2009. The duration of prograde garnet crystallization in the UHP eclogites at Lago di Cignana, Italy. Earth and Planetary Science Letters 287, 402-11.

Skora, S., Mahlen, N. J., Johnson, C. M., Baumgartner, L. P., Lapen, T. J., Beard, B. L. \& Szilvagyi, E. T. 2015. Evidence for protracted prograde metamorphism followed by rapid exhumation of the Zermatt-Saas Fee ophiolite. Journal of Metamorphic Geology 33, 711-34.

Spalla, M. I., Gosso, G., Marotta, A. M., Zucali, M. \& SALVI, F. 2010. Analysis of natural tectonic systems coupled with numerical modelling of the polycyclic continental lithosphere of the Alps. International Geology Review 52, 1268-302.

SPEAR, F. S. 1993. Metamorphic Phase Equilibria and Pressure-Temperature-Time Paths. Mineralogical Society of America, Chelsea, Michigan: BookCrafters, Inc., $799 \mathrm{pp}$.

Springer, K., Lapen, T. J., Baumgartner, L. P., Johnson, C. M. \& BeARD, B. L. 2009. Sm-Nd geochronology of the Zermatt-Saas ophiolite, northern Italy. Geochimica et Cosmochimica Acta (Supplement) 73, p. A1258.

Steinmann, G. 1927. Die ophiolitshen zonen in den mediterranen Kettengebirgen, translanted and reprinted by Bernoulli and Friedman. In Ophiolite Concept and the Evolution of Geologic Thought (eds Y. Dilek \& S. Newcomb), pp. 77-91. Geological Society of America, Special Publication, 373.

Stoeckhert, B. \& Gerya, T. 2005. Pre-collisional high pressure metamorphism and nappe tectonics at active continental margins: a numerical simulation. Terra Nova 17, 102-10.

Tiepolo, M., Tribuzio, R. \& Vannucci, R. 1997. Mg- and Fe-gabbroids from Northern Apennine ophiolites: Parental liquids and igneous differentiation process. $O f i-$ oliti 22, 57-70.

Tribuzio, R., Garzetti, F., Corfu, F., Tiepolo, M. \& RENNA, M. R. 2016. U-Pb zircon geochronology of the Ligurian ophiolites (Northern Apennine, Italy): Implications for continental breakup to slow seafloor spreading. Tectonophysics 666, 220-43. van Achterbergh, E., Ryan, C. G., Jackson, S. E. \& GRIFFIN, W. 2001. Data reduction software for LAICPMS. In Laser ablation ICPMS in the Earth Sciences: Principles and Applications (ed. P. Sylvester), pp. 239-43. Mineralogical Association of Canada, Short Course Series 29.

van Der Klauw, S. N. G. C., Reinecke, T. \& Stöckhert, B. 1997. Exhumation of ultrahigh-pressure metamorphic oceanic crust from Lago di Cignana, Piemontese zone, Western Alps. Lithos 41, 79-102.

WeBER, S. \& BUCHER, K. 2015. An eclogite-bearing continental tectonic slice in the Zermatt-Saas high-pressure ophiolites at Trockener Steg (Zermatt, Swiss Western Alps). Lithos 232 336-59.

Weber, S., Sandmann, S., Miladinova, I., Fonseca, R. O. C., Froitzheim, N., MuN̈Ker, C. \& Bucher, K. 2015. Dating the initiation of Piemonte-Liguria Ocean subduction: Lu-Hf garnet chronometry of eclogites from the Theodul Glacier Unit (Zermatt-Saas zone, Switzerland). Swiss Journal of Geosciences 108, 18399, doi: 10.1007/s00015-015-0180-5.

Wiedenbeck, M., Allé, P., Corfu, F., Griffin, W. L., Meier, M., Oberli, F., Von Quadt, A., Roddick, J. C. $\&$ SPIEGEL, W. 1995. Three natural zircon standards for $\mathrm{U}-\mathrm{Th}-\mathrm{Pb}, \mathrm{Lu}-\mathrm{Hf}$, trace elements and REE analyses. Geostandards Newsletter 19, 1-23.

Zanoni, D., Rebay, G., Bernardoni, J. \& Spalla, M. I. 2012. Using multiscale structural analysis to infer high/ultrahigh-pressure assemblages in subducted rodingites of the Zermatt-Saas Zone at Valtournanche, Italy. In Multiscale Structures and Tectonic Trajectories in Active Margins (eds M. Zucali, M. I. Spalla \& G. Gosso), paper 6. Journal of the Virtual Explorer 41.

ZaNoni, D., Rebay, G. \& Spalla, M. I. 2016. Ocean floor and subduction record in the Zermatt-Saas rodingites, Valtournanche, Western Alps. Journal of Metamorphic Geology 34, 941-961. doi: 10.1111/jmg.12215.

Zanoni, D., Spalla, M. I. \& Gosso, G. 2010. Structure and PT estimates across late-collisional plutons: constraints on the exhumation of western Alpine continental HP units. International Geology Review 52(10-12), 1244 67.

Zucali, M., Spalla, M. I. \& Gosso, G. 2002. Strain partitioning and fabric evolution as a correlation tool: the example of the eclogitic micaschists complex in the SesiaLanzo Zone (Monte Mucrone-Monte Mars, Western Alps Italy). Schweizerische Mineralogische und Petrographische Mitteilungen 82, 429-54. 